\section{UCDNN}

LIBRARY
University of Connecticut OpenCommons@UConn

Faculty Articles and Papers

School of Law

1989

\title{
Charles Guiteau and the Christian Nation
}

Carol Weisbrod

University of Connecticut School of Law

Follow this and additional works at: https://opencommons.uconn.edu/law_papers

Part of the Law and Psychology Commons, and the Law and Society Commons

\section{Recommended Citation}

Weisbrod, Carol, "Charles Guiteau and the Christian Nation" (1989). Faculty Articles and Papers. 321.

https://opencommons.uconn.edu/law_papers/321 


\section{HEINONLINE}

Citation: 7 J. L. \& Religion 1871989

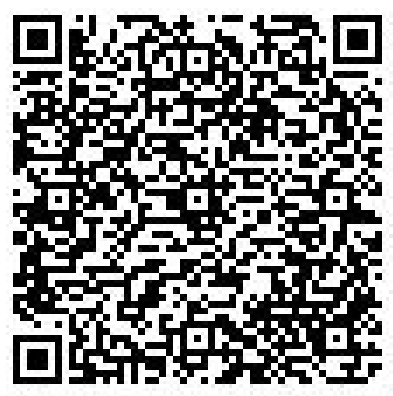

Content downloaded/printed from

HeinOnline (http://heinonline.org)

Mon Aug 15 18:31:42 2016

-- Your use of this HeinOnline PDF indicates your acceptance of HeinOnline's Terms and Conditions of the license agreement available at http://heinonline.org/HOL/License

-- The search text of this PDF is generated from uncorrected OCR text.

-- To obtain permission to use this article beyond the scope of your HeinOnline license, please use:

https://www.copyright.com/ccc/basicSearch.do?

\&operation $=$ go\&search $\mathrm{Type}=0$

\&lastSearch $=$ simple\&all=on\&titleOrStdNo $=0748-0814$ 


\title{
CHARLES GUITEAU AND THE CHRISTIAN NATION
}

\author{
Carol Weisbrod*
}

\section{INTRODUCTION}

This issue of the Journal of Law and Religion, dedicated to the memory of Robert M. Cover, publishes a variety of work in his honor. Some of that work takes Cover's scholarship as its subject. Other pieces may stand in a less direct, but no less important, relation to Cover's interests. The following article on the trial of Charles Guiteau is in the second category. The direct citations to Cover seem less significant than the larger sense in which this piece is connected to fundamental themes in Cover's work.

The trial of Charles Guiteau for the assassination of James Garfield is used as the point of entry for a treatment of law and religion in 19th century America. A biblical text, Genesis 22, provides a focus for a discussion of a culture engaged in a debate over science and religion. This in itself would have interested Bob Cover, who was deeply concerned with the multiple meanings of religious and other normative texts as well as with problems of legal pluralism and the reality of competing normative orders. The relationship of official law and higher law, with an emphasis on the role of the judge, was the focus of Cover's Justice Accused. Problems of legal pluralism and of law and violence, were the subjects of much of the work that followed, including the discussion of conflict underlying the idea of "redundant jurisdiction" and the treatment of multiple ordering in "Nomos and Narrative." Placed in this framework, the trial of Guiteau litigated the issue of individual antinomianism, the ultimate problem of pluralism.

While Cover's substantive concerns are well known, his scholarly method-artificially divided here from substance-is commented upon less often. Cover's work was sometimes historical, in the sense

- Professor of Law, University of Connecticut School of Law, Hartford, Connecticut.

Over a number of years, people in various fields (including several anonymous reviewers) have been kind enough to read and offer comments on drafts of this work. I would like particularly to thank Ellen Dwyer, Gordon Goldberg, Judah Goldin, Richard S. Kay, Leon Lipson, Kent Newmyer, Bruce Mann, Martha Minow, Carl Schneider, Mark Sheingorn, Pamela Sheingorn, Aviam Soifer, and Larry Yackle for their assistance. I would also like to record a special debt to the late Dorothy Lipson. Finally, I acknowledge with thanks support received from The University of Connecticut School of Law and the University of Connecticut. 
that its subject and materials were located in the past. But it was never narrowly historical. His reading, his range of reference, and the level of question which absorbed him went far beyond what would be common in the work of professional historians. At the same time, the detail of his historical discussion was deeper than is common in the work of professional legal academics. Cover transformed the common idea of the law teacher as not limited by disciplinary constraints (though limited, often, by the need to know something fast for some particular purpose) into the model of the law teacher as intellectual, driven, if anything, by the need to know for itself, and the need to integrate in order to know. Cover easily engaged a number of the "Law Ands" of current academic life. No one of those would have defined his interests. In this, Cover provided encouragement directly and by example for those whose aspirations and understandings were in the same direction. For this reason also, the present inquiry, dealing with materials from law, medicine, and religion, however problematic it might be from the point of view of specialists, is one to which Cover would, I think, have been sympathetic. It seems to me appropriate that this article should be published as part of a special issue dedicated to him.

On July 21, 1881, Charles Guiteau shot President James Garfield in the train station in Washington, D.C. Garfield lingered for some time and finally died on September 19, 1881. Guiteau was found fit to stand trial and his trial lasted over two months. The significant publicity which attended the trial was commented upon by prosecution psychiatrist John Gray: "[u]nder our form of government, a crime of this nature still continues to be so phenomenal in its character as to excite speculation to the highest degree when searching for some possible and adequate motive."1

1. Gray, Guiteau, "The Guiteau Trial" 38 Am. J. Insanity 303, 304 (1882) thereinafter Gray, The Guitean Trial].

The basic secondary work on the Guiteau trial is C. Rosenberg. THE Trial of THE Assassin Guiteau: Psychiatry and Law in the Gilded Age (1968) [hereinafter RoSENBERG], which offers a full narrative of the trial and includes a useful bibliographic essay. The basic source is the text of the trial, which has been republished in two volumes. The United States vs. Charles J. Guiteau, Mental Illness and Social Policy: The American Experience (1973) [hereinafter Trial].

I have attempted here to argue from particular religious references to an underlying intellectual orientation. This attempt, to the extent that these references are not, of course, the only references made, results in a distortion of the whole. The trial was not, after all, dominated by debate over the story of Abraham and Isaac in Genesis 22.

This distortion can be corrected by reading Professor Rosenberg's fine account of the trial. Rosenberg, supra. There is no claim here that an understanding of the Guiteau trial 
Guiteau, by counsel, formally defended the case on the basis of the insanity defense, arguing that he was too lacking in mental capacity to be found criminally accountable for the murder of the President. However, throughout his trial, Guiteau himself, serving as if he were his own counsel, argued a somewhat different defense, comparing himself to the Biblical Abraham ${ }^{2}$ and defending on the basis of

which included the religious dimension was the dominant understanding of the culture. That is, there is no claim that this reading reaches the "essence" of the Guiteau trial. See D. Fischer, Historians' Fallacies: Toward a Logic of Historical Thought (1970). There is a claim that this way of understanding the trial should be added to our sense of what the Guiteau trial was about.

This discussion is based on printed sources, and at some points I have used substantially all the material I had. That is, this is not work in which every quotation is chosen from a set of similar ones. At the same time, it seems entirely likely that other sources exist somewhere which reveal similar perspectives.

See also Gaylord, Guiteau's Case, CASE AND Comment, July/Aug. 1981, 33-41 (briefly raising the issue of the possible truth of the revelation); C. ROSENBERG, THE CHOLERA YEARS: THE UNITED STATES IN 1832, 1849 and 1866 (1962) (providing a very useful background of the changes in the intensity of religious concerns in the 19th century). For a fictional appearance of Guiteau, see J. OATES, A BloOdsmoOR Romance 107, 247 (1982).

The significance of a religious orientation in late 19th century America is beyond debate. See Friedman, Exposed Nerves: Some Thoughts on Our Changing Legal Culture, 17 Suffolk U. L. REv. 529539 (1983) (referring to a quasi-official religion). See also L. FriedmaN, TOTAL JUSTICE 113-14 (1985). The problem is to find specific indications of impact.

Tracing intellectual influences of any kind can present difficulties. This is true even with reference to social Darwinist influence, which seems to show up less often than one might have expected. See A. Paul, Conservative Crisis and the Rule of LaW: Attitudes of Bar AND BENCH 1887-1895 22, 23 n.10 (1969) ("Although Spencerian Social Darwinism was doubtless an important ingredient in the ideology of laissez-faire conservatism, only a very few of the hundreds of bar association speeches examined for this study contained specific references to Spencer.") see also Hollinger, Spencer, Scientism and American Constitutional Law, 33 ANNALS OF SCIENCE 476 (1976) ("Social Darwinism can now claim a dubious honor, that it can be shown not to have existed in more places than has any other movement in the history of social history.") (I am grateful to Avi Soifer for providing me with this reference.)

2. See Genesis 22:

1. AND it came to pass after these things, that God did tempt Abraham, and said unto him, Abraham: and he said, Behold, here I am.

2. And he said, Take now thy son, thine only son, Isaac, whom thou lovest, and get thee into the land of Mo-ri-ah; and offer him there for a burnt offering upon one of the mountains which I will tell thee of.

3. And Abraham rose up early in the morning, and saddled his ass, and took two of his young men with him, and Isaac his son, and clave the wood for the burnt offering, and rose up, and went unto the place which God had told him.

4. Then on the third day Abraham lifted up his eyes, and saw the place afar off. 5. And Abraham said unto his young men, Abide ye here with the ass; and I and the lad will go yonder and worship, and come again to you.

6. And Abraham took the wood of the burnt offering, and laid it upon Isaac his son; and he took the fire in his hand, and a knife; and they went both of them together. 7. And Isaac spake unto Abraham his father, and said, My father; and he said, Here am I, my son. And he said, Behold the fire and the wood: but where is the lamb for a burnt offering?

8. And Abraham said, My son, God will provide himself a lamb for a burnt offering; so they went both of them together. 
divine inspiration and responsibility. The jury found Guiteau guilty, and an appeal failed. The law having declared him sane and responsible, Charles Guiteau was executed on June 30, 1882.

It is common today for historians to see Guiteau as insane. ${ }^{3}$ For instance, Professor James W. Clarke writes that "[w]ith the single exception of Richard Lawrence [who tried to kill Andrew Jackson in 1835], there has been no American assassin more obviously deranged than Charles Guiteau."4 But Clarke's perception is troubling: a

\footnotetext{
9. And they came to the place which God had told him of; and Abraham built an altar there, and laid the wood in order, and bound Isaac his son, and laid him on the altar upon the wood.

10. And Abraham stretched forth his hand, and took the knife to slay his son.

11. And the angel of the Lord called unto him out of heaven, and said, Abraham, Abraham: and he said, Here am I.

12. And he said, Lay not thine hand upon the lad, neither do thou any thing unto him: for now I know that thou fearest God, seeing thou has not withheld thy son, thine only son from me.

13. And Abraham lifted up his eyes, and looked, and behold behind him a ram caught in a thicket by his horns: and Abraham went and took the ram, and offered him up for a burnt offering in the stead of his son.
}

Genesis 22; 1:13 King James Version.

3. John H. Cassity, M.D., said in 1958, "Charles Guiteau was undoubtedly a common garden variety of paranoid schizophrenia." J. CASSITY, THE QUALITY OF MURDER 30 (1958). More recently Tom Wicker commented that, "'[Guiteau] was mad as a hatter'-believing, among other things, that God had directly instructed him to dispose of Garfield." Wicker, "How Loose Must the Screw Be?", New York Times Book Review, September 17, 1982. (Review of A. Mayer and M. Wheeler, The Crocodile Man: a Case of Brain Chemistry and Criminal Violence (1982). Cf. H. Thoreau, Walden and Other Writings 704 (1950) (on John Brown) ("Newspaper editors argue also that it is proof of his insanity that he thought he was appointed to do this work which he did-that he did not suspect himself for a moment! They talk as if it were impossible that a man could be 'divinely appointed' in these days to do any work whatever ..."). See also M. Keller, AfFairs of STATE: PUblic Life in Late Nineteenth Century AMErica 267.268 (1977) (linking Guiteau's insanity to a description of him as a disappointed office-seeker without discussion of the religious insanity issue).

Soon after Garfield's inauguration, Guiteau expressed his interest in political positions in Europe. Thus we get the image of Guiteau as a disappointed office seeker. The assassination of Garfield is said to have expedited civil service reform. See R. HofSTADTER, ANTI-INTELLECTUALISM IN AMERICAN LIFE 185 (1962). However, Guiteau was in fact not an office seeker in any ordinary sense. Professor Rosenberg suggests that he was "rather a victim of mental illness whose delusional system prescribed this role for him." (Rosenberg, supra n.1, at ix).

4. J Clarke, american Assassins: The Darker Side of American Polmics 198 (1982). Professor Clarke, a political scientist, offers a classification of assassins and indicates that certain assassins (including Guiteau) "are characterized by severe emotional and cognitive distortion that is expressed in hallucinations and delusions of persecution and/or grandeur. Their contact with reality is so tenuous that they are usually unable to grasp the significance of their actions or understand the response of others to them. As a rule, their acts are mystically or 'divinely' inspired-in a word, irrational or insane." Id. at 16. Noting that "[t]hroughout his lengthy seventy-two-day trial, Guiteau's delusional state was apparent to anyone inclined to acknowledge it," Professor Clarke offered the history of insanity in the Guiteau family. Id. 
world relatively close to our own, which recognized that the insane ought not to be punished, nonetheless punished Guiteau.

The problem which requires explanation is thus not the motive or mindset of Guiteau, whose insanity we are willing to accept, but that of the culture which hanged him. One explanation for Guiteau's execution might be that in this instance, insane or not, the murderer had to die. In his 1968 study of the trial, Professor Charles Rosenberg noted: "[C]ommon sense suggests that no American jury in 1881 would have dared to vote to acquit Guiteau."s Guiteau had to be hanged because Garfield died, and calling him insane would have excused him from hanging. In short, the execution of a clearly insane man can be seen as the act of a vengeful society responding to a man perceived as a regicide.

One might, as another possibility, probe the option that, while the insane were not to be punished, the late 19th century view of insanity was not the same as ours. While Guiteau's "eccentricity" was undeniable, according to Professor Rosenberg, it was not enough for a defense based on insanity. Guiteau may seem "obviously deranged" to us and to some of his contemporaries; but the matter of Guiteau's medical, and then legal, insanity was a much more difficult issue in the 19th century.

In one sense, the question of Guiteau's sanity hinged on the debate between nonreligious defense psychiatrists Kiernan and Spitzka, whose arguments were widely understood as dangerous, and more traditional views, as represented by prosecution psychiatrist John Gray.

The defense argument was considered an apologetic for evil, and it raised fears that loose theories of insanity would simply excuse wickedness in the name of the insanity defense. ${ }^{6}$

at 209, 210. A major emphasis of the defense psychiatrists at the trial was on this hereditary insanity.

5. RosenberG, supra note 1, at 99 ("Few Americans .. . doubted Guiteau's eccentricity and peculiarity of temperament. It was equally clear that he would hang.") Rosenberg also notes that "Americans in 1881, especially those living in rural areas, seemed able to tolerate a far greater degree of deviant behavior than is ordinarily the case today.... The result was that one might be a fanatic in religion or politics, even a compulsive thief or murderer, and still appear to be within the range of responsible behavior." Id. at 53-54. This approach was, however, a matter of "formal beliefs."

Particular cases might yield different results, as where a parent slew his child at the command of Jehovah. Here, "conventional wisdom found no difficulty" in finding insanity, although, Rosenberg indicates, a "strict construction" of the legal rules might not permit this. Id. at 54. On the "Conventional Wisdom" see discussion below, of the responses to the Freeman case.

6. ROSENBERG, supra note 1 , at 184-85. 
Prosecution witness Gray, Professor Rosenberg writes, was the "most prominent American defender of a narrow interpretation of criminal responsibility and in general a staunch upholder of religion, social order, and traditional morality." Gray, a member of the theologically orthodox Reformed Church, "regarded mental hygiene in significant measure as a problem of religious education," along with many of his contemporaries. He "saw no possibility of real conflict between science and religion-except in the case of that 'puffed up' science which presumed to explain God's moral world in terms of force and matter." 8

This essay considers the Guiteau trial in relation to problems of religion and law. The present treatment builds on Professor Rosenberg's discussion. That study used the Guiteau trial to reach "the reactions of Americans in the gilded Age to mental illness, to psychiatry, and to individual character and personality." Rosenberg attempted to reconstruct the trial so as to "create a microcosm of American psychiatry in the 1880 's." 10 The enterprise here is a different one. In considering the relationships between religion and law in America, legal scholarship has often focused on specific litigated issues of church and state. Scholarship addressed to legal history, even when oriented to broad issues of law and society, has tended to stress problems associated with economic development. While some work makes plain the importance of connections between religion and law in general, monographic work which deals with the significance of the older religious orientation for the American legal system seems much needed. This reading of the Guiteau trial, which sees the trial as an intersection of law and religion, and as part of the law of church and state, is offered as a contribution to that effort.

The Guiteau trial seems appropriate as a vehicle for a broad inquiry into the relationship between religion and law in that era, because of the peculiar drama of the Guiteau trial and because of the nature of the arguments which Guiteau raised in his defense. Professor Morton White observed that as a general matter, "catastrophes are peculiarly suitable aids in tracing the history and development of ideas and intellectual currents." " More particularly, as Professor

7. RosenberG, supra note 1 , at 190.

8. Id. at 90 .

9. Id. at $\mathrm{x}$.

10. Id. at xii.

11. M. White, Social Thought in America: The Revolt Against Formalism 3 (1957). 
Rosenberg suggested in his study, Charles Guiteau "chose unerringly among the most meaningful values and preconceptions of American life." Guiteau looked for "success through morality and self-improvement, evangelical religion, enthusiastic politics, and venturesome business enterprise." 12

It is Guiteau's association with, and arguments from, religion which are of interest here. Guiteau argued that in a Christian Nation, he should be acquitted of the assassination of the President because he had been divinely inspired to kill the President. Guiteau "said in so many words that he did not believe his own plea; he himself thought the inspiration real and would have been pleased if the jury had brought him in not guilty, as doing God's will."13 He urged, as one alienist put it, "that the jury should call his inspiration insanity and so acquit him."14 But Guiteau's argument was rejected by the jury.

At the heart of the Guiteau trial is the certainty of the culture that there was no Divine intervention into national affairs through Charles Guiteau. As a late nineteenth century psychiatrist, Dr. Godding, wrote in his discussion of Guiteau, "[t]he education of the mass of mankind, if it deals with inspiration at all, treats it as a thing of the distant past. ... For thousands of years it has been the all but universal belief that direct inspiration is no longer to be expected."15 This certainty, this "all but universal belief" was the product of a general intellectual development of the issue of direct revelation; and in the Guiteau trial, the certainty of a culture was visible as an aspect of our civil religion.

In part, this essay details the role of religious belief and action in American life as it came together in the law of insanity in the late nineteenth century. The legal categories through which Guiteau's argument was rejected brought together the law of church and state and the law of the insanity defense. At the Guiteau trial, there was no issue of revelation in fact. The fact that there had been no inspiration

12. ROSENBERG, supra note 1 , at 258.

13. W. IRELAND, Through the IVORY GATE 216 (1889).

14. Id. at 216.

15. W. Godding, Two Hard Cases: Sketches From a Physician's Portfolio 168 (1882). See generally Rosen, Enthusiasm, 42 BULLETIN OF THE HiSTORY OF MEDICINE 410 (Sept. 6, 1968).

Godding concluded by saying "for thousands of years it has been the all but universal belief that direct inspiration is no longer to be expected, and that he who claims now that he hears the audible voice of God, or with mortal eyes sees the Lord, must be insane." See discussion of sensory claims below. 
or command was taken as given. That raised, then, the issue of belief and particularly the issue whether a belief could excuse a criminal act.

The "law on religious belief" can be found in different parts of the legal system ranging from religious tests for public office to questions of insanity. One part of the law on religious belief is illustrated by the 1879 Mormon polygamy case, Reynolds v. United States, ${ }^{16}$ which held that there was no first amendment (free exercise) defense to a polygamy prosecution, distinguishing between protection of religious belief and protection of religious action based on that belief. Another part of the law, an example of the religious delusion which would excuse under the insanity defense, is presented by the case of Charles Freeman, the Pocasset murderer, ${ }^{17}$ called "the modern Abraham" by George Beard. ${ }^{18}$ This 1879 tragedy involving the death of Freeman's daughter is important for an understanding of the trial of Charles Guiteau, because Freeman's case can be seen as the model of religious insanity against which Guiteau's insanity claim was being tested. $^{19}$

But more importantly, this essay is based on the proposition that the religious perspectives so evident in the first half of the nineteenth century had by no means disappeared by the end of the century, and that they are significant for an understanding of the Guiteau trial. That religious perspectives infused the culture is evidenced by the fact that a legal journal discussing Garfield's assassination could include, without explanation of relevance, both a brief reference to Abraham and a discussion of Judith and Holofernes. ${ }^{20}$ Yet the tension in the culture was clear: "Darwinism, the emerging science of biblical criticism, the increasing knowledge and study of other great religionssuch threats to orthodoxy could not be ignored. . ." in this critical period in the history of American religion. ${ }^{21}$ Merle Curti wrote that,

16. Reynolds v. United States, 98 U.S. 145 (1879).

17. See infra p. 217.

18. G. Beard, The Case of Guiteau-A Psychological Study 9 (1882).

19. The Pocasset case was one of a number of insane delusion cases discussed which involved divine command. Several of these related specifically to children. See 2 Trial, supra note 1, at 1538-39. In general, the killing of one's own children, particularly where the killer was the mother, was often treated as insanity in the 19th century.

20. The Law Central No. 3 (Smith ed. 1881). The Journal also included a comparison of the cases of Judith and Charlotte Corday (the assassin of Marat) noting that: "There was no insanity in Judith's case. It was SAGACITY INSPIRED. That was an age when men and women were permitted to act on the admitted assumption of high incentives from the Almighty; for we are not allowed to suppose that Abraham was insane when he prepared, in the most solemn manner, to sacrifice and to slay his son." (at 143).

21. Schlesinger, A Critical Period in American Religion, 1875-1900, 64 Proceedings of MASSACHUSETtS Historical SOCIETY 522, 524 (1932). 
"[t]he most striking event in the intellectual history of the last third of the nineteenth century was the blow dealt the historic doctrine of supernaturalism - the doctrine that a divine Creator stands above the laws of nature and intervenes directly in natural events and the affairs of men through miracles and the granting of grace-by new developments in the biological and physical sciences." 22 At the Guiteau trial, one threat to orthodoxy was suggested by the testimony of agnostic defense psychiatrists; another opposite threat to contemporary beliefs about religious supernaturalism was evident in Guiteau's higher law defense.

After he was found guilty on January 25, 1881 (following a rather short jury deliberation), Guiteau said about the jury which had declared him guilty that they "did not pretend to be Christian men" and therefore "did not appreciate the idea of inspiration." The jury are "men of the world," Guiteau said, and "of moderate intelligence," and were therefore "not capable of appreciating the character of my defense." ${ }^{23}$ But exactly the reverse may have been true. Perhaps Guiteau had to be convicted because, in a culture which viewed itself as part of Western Christendom, the theory which he offered to establish the insanity defense implicated biblical religion at exactly a time when it was under heavy attack, facing challenges from several directions. For some, therefore, Guiteau's troublesome argument could perhaps not simply be ignored or viewed as another symptom of psycho-pathology. It had to be completely rejected.

\section{Background: Christians and the Christian Nation}

"But what became of the prayers?"24

Before reaching the substance of Guiteau's defense to the charge of murdering James Garfield, it may be useful to consider the Christian background of Guiteau, and the jury. The idea of a Christian Nation as described by Protestant spokesmen Samuel D. Spear and Josiah Strong, as well as Justice David J. Brewer's 1905 discussion of the question, helps to frame the argument which Guiteau was making.

22. M. Curti, The Growth of American Thought 517 (3d ed. 1964). If supernaturalism was "losing ground among intellectuals, it was by no means, in the post-Civil War period, on the road to extinction among the masses." (Id. at 519) without forcing the issue of "the masses", one may note again the composition of the Guiteau jury.

23. Guiteau, Appeal to the American People, January 26, 1882 (quoted in Rosenberg, supra note 1 , at 224).

24. The Independent, September 29 (1881). 
At a certain level, at least, the issue of Guiteau as a Christian is readily dealt with. Born in Illinois in 1841, Charles Guiteau was raised in an intensely religious environment. His father was a spiritual disciple of the Perfectionist leader John Humphrey Noyes. ${ }^{25}$ Charles Guiteau himself lived at Oneida, the community which implemented Noyes' controversial ideas relating to sexual and economic arrangements, for a number of years. Guiteau considered himself both a lawyer and a theologian, and wrote and lectured on religious subjects. He was, as the free thinker Robert Ingersoll noted, "[a] follower of Moody and Sankey, and [he] was probably instrumental in the saving of a great many souls." 26

The sense in which evangelical religion was among the most basic values of 19th century American life, the sense, in short, in which America was a Christian Nation, is more difficult to address. Much depends on the precise question being asked. For lawyers, the question frequently comes up as part of a legal argument concerning the constitutionality of a piece of state behavior. The result of the litigation will be yes or no; and lawyers, using the past as part of a legal argument, will, thus, tend to present the historical record as unambiguous. For historians, the record seems more complex. The Federal Constitution directed that there be no establishment of religion. The states had disestablished their churches long before the civil war. Nonetheless, Christian Nation rhetoric can be found in even official materials. The question then becomes "to what degree a Christian Nation?" or "in what way?" America may have been all too often a Christian Nation from the point of view of a non-Christian immigrant, ${ }^{27}$ while it evidenced too much evil to be called a Christian Nation from the point of view of professing Christians. ${ }^{28}$

One can explore the state of the Christian Nation question at the time of the Guiteau Trial by bracketing the trial with two discussions

25. Professor Rosenberg provides this description of Luther Guiteau's beliefs. "By any standards, his religious opinions were extreme-even in an age still harboring an abundance of evangelical enthusiasm. The world was a very dramatic place to Luther Guiteau, one which he viewed in essence as a stage for the confrontation of God and the Evil One; each soul, and indeed every happening in the world, was an objective to be gained in this continuing struggle. Selfish or sinful actions, he always explained, were a consequence of submission to the pervasive forces of Evil; benevolence came only through faith and submission to God. No action, however small, could be ignored." Rosenberg, supra note 1, at 14.

26. THE WORKS OF ROBERT INGERSOLL: INTERVIEWS 102 (1900). For a discussion of Dwight L. Moody, see G. Marsden, Fundamentalism And American Culture 32.39 (1980).

27. M. BORDEN, JEWS, TURKS AND INFIDELS (1984).

28. See M. Noll, The Search for Christian America (1983). 
of the question by Protestant spokesmen. In 1876, Reverend Samuel D. Spear, writing on the proposed Christian National amendment to the Federal Constitution, attempted to discuss the ways in which the country was and was not a Christian Nation. ${ }^{29}$ Spear noted that it was clearly true that the American government was not Christian in the sense intended by the proposed constitutional amendment. It was, however, "true that the Constitution establishes a 'Christian government' in the sense of providing for those great moral ends that refer to the present welfare and happiness of society." 30 Unity, common defense, general welfare and the like are, he urged, surely "not antiChristian ends"; and, further, "it is not straining the import of the term to say that they are Christian, considered with reference to the department of Christianity which relates to the interests and duties of time." ${ }^{31}$ He concluded that in this sense, the government of the United States under the Constitution was already Christian. In another discussion of the issue, he suggested that the country was a Christian country in the sense that "Christianity is the religion which has the greatest prevalence among the people, and exerts far the greatest influence upon their thoughts, habits and usages, and in this way reaches and affects the policy of the state in its legal operations." ${ }^{32}$

Ten years after Spear's treatment of the question, the Protestant minister Josiah Strong's Our Country mirrored "the thoughts and aspirations of the dominant segment of American society towards the close of the nineteenth century" toward America as a Christian Nation. ${ }^{33}$ In Strong's book, in addition to the powerful Protestant vision of the significance of America, one sees also the sense of crisis which Protestant America felt. Strong opened his book with this observation: "There are certain great focal points of history toward which the lines of past progress have converged, and from which have radiated the molding influences of the future." These points included the incarnation, the reformation, and "the closing years of the nineteenth century, second in importance only to ... that only which must al-

29. S.D. Spear, Religion and the State of the Bible and the Public Schools, 213 (1876) ("Religious Amendment of the Constitution"). The amendment he was discussing read: "We, the people of the United States, acknowledging Almighty God as the source of all authority and lower in civil government, the Lord Jesus Christ as the ruler among the nations, and his revealed will as of supreme authority, in order to constitute a Christian government, to form a more perfect union. ..."

30. Id. at 214.

3L Id.

32. Spear, p. 370. ("fragmentary Thoughts").

33. J. Strong, Our CounTry (1886 1891), at ix (1963) (introduction by Jurgen Herbst ed.) (hereinafter Strong). 
ways remain first; viz the birth of Christ." ${ }^{34}$

Strong's list of perils to the Christian nation included Romanism, Mormonism, and particularly the problem of religion and the public schools, the context for his discussion of the relation between church and state. Quoting Story and Webster on Christianity and the general law, he finds that while separation of church and state was mandated in America, "there was no intent to separate the state from all religion ...." And as to the relationship between Christianity, the United States, and millennial dream, Strong is very clear. "Notwithstanding the great perils which threaten it, I cannot think our civilization will perish: but I believe it is fully in the hands of the Christians of the United States, during the next ten or fifteen years, to hasten or retard the coming of Christian Kingdom in the world by hundreds and perhaps thousands of years." 33 Strong's book cannot simply be taken as the representative statement of a small religiously oriented minority. The book was a great commercial success. In its impact, it was compared to Uncle Tom's Cabin.

For the purpose of this essay, the 1905 discussion of the Christian Nation question, by Supreme Court Justice David J. Brewer is also useful if only to reinforce the point that the Christian Nation idea had by no means disappeared by the end of the nineteenth century. The United States was a Christian Nation, Brewer argued, though in "a very special sense." "This republic is classified among the Christian nations of the world," he said. "It was so formally declared by the Supreme Court of the United States." In Holy Trinity Church v. United States, "that Court, after mentioning various circumstances, added, 'these and many other matters which might be noticed, add a volume of unofficial declarations to the mass of organic utterances that this is a Christian nation." "37

"But in what sense can it be called a Christian nation?," Brewer asked. "Not in the sense that Christianity is the established religion or that the people are in any manner compelled to support it." Indeed, the opposite was true, for the American Constitution specifically provides that "Congress shall make no law respecting an establishment of religion, or prohibiting the free exercise thereof." Further, America was not a Christian Nation "in the sense that all its citizens are either in fact or name Christians." Again, the opposite

34. Id. at 13 (emphasis in original).

35. Id. at 218.

36. D. Brewer, The United States: A Christian Nation 12 (1905).

37. Id. at 11 . 
was the case: "(a)ll religions have free scope within our borders. Numbers of our people profess other religions, and many reject all." And finally, this was not a Christian Nation in the sense that a profession of Christianity is a condition of holding office or otherwise engaging in the public service, or essential to recognition either politically or socially." For in America "the government as a legal organization is independent of all religions." Nevertheless, Justice Brewer said, "we constantly speak of this republic as a Christian nation-in fact, as the leading Christian nation of the world. This popular use of the term certainly has significance." 38

Initially then, while the Christian amendment to the Constitution was never adopted, ${ }^{39}$ we should be clear that the Christian perspectives so evident in the first half of the nineteenth century were still strong at the end of the century. ${ }^{40}$ At the trial, one threat to these conventional religious ideas was presented in the testimony of agnostic psychiatrists' urging Guiteau's insanity. ${ }^{41}$ Another threat to orthodoxy was evident in Guiteau's antinomianism; and his "higher law" defense ${ }^{42}$ that continuing revelation was possible and real, and

38. Id. at 12 .

39. On the Christian Amendment, see L. Pfeffer, Church, State And Freedom 241, 242 (1967); M. Borden, supra.

40. The old order was under attack. But this is quite different from saying that the old order was dead. The tension is caught in an anecdote about President Grant:

While medical experts injected brandy into Grant's veins, Newman seized a bowl of water and baptized the unconscious man according to the rites of the Methodist Church. As the patient revived, the cleric exclaimed, "It is Providence!" "No," replied the scientist, "it was the brandy!" W. Hesseltine, Ulyses S. Grant: Politician 452 (1953) [quoted in P. Carter, Spiritual Crisis of the Gilded Age 85 (1971)].

The co-existence of older and newer ideas is evident in some comments of Guiteau himself. Guiteau invoked a decision of a New York court, saying that it "revolutionizes the old rule," is a "grand step forward in the law of insanity," and is "worthy of this age of railroads, electricity, and telephones." And then he said, "I have no hesitation in saying that is a special Providence in my favor. . . ." 2 Trial, supra note 1, at 2203.

41. See ROSENBERG, supra note 1, at 166-69. Guiteau's argument on his own insanity was, of course not the same as that of the defense psychiatrists. Rosenberg quotes a note from Guiteau to his brother, saying that there should not be an attempt to prove actual insanity. "It would disgust the court and the jury. Legal insanity is all I claim." ROSENBERG, supra note 1, at 87.

42. In a system in which there is a clear religious authority (which can then decide what is and is not possible and therefore what is and is not delusion), religious insanity, while it may exist, poses no intellectual difficulty. A consequence of systematic separation of church and state is that while religious authorities still exist, they no longer operate directly in the public sphere to define reality. On what basis then does the state-officially removed now from questions of religious doctrine--determine who is insane when a disease of the mind is evidenced by religious delusions? It seems that the issue is sometimes dealt with by treating the problem as one rather like the problem of judicial notice. The things of which judicial notice is taken may be weights and measures or the existence of witches, or the possibility of communication with the dead or of supernatural duress. All are based on conventional perceptions of reality. 
that such revelation, as divine inspiration, justified practices illegal under the law of the state.

The period following the shooting of James Garfield in the Washington train station resulted, according to some observers, in an unusual feeling and tone in the United States. Americans had shared not only the experience of mourning the death of President Garfield, but also the weeks of uncertainty as to whether the President would live or die. It was suggested that the time was flatly unprecedented in that the world was, to some considerable degree, present in the sick room for three months, watching the medical profession working to save the President. ${ }^{43}$ The idea that the time had a special quality for America is found in comments such as this one from Russell Conwell: "The bond of a common grief united the people with each other," Conwell wrote, "and the sufferings of the afflicted President and his wife at Washington lifted the American people into a purer sphere. . . ."44

The sermon delivered by Rev. S.D. Power at the President's church in Washington (eight weeks after the shooting and at a time when there was some indication of an improvement in President Garfield's condition) suggests what is likely to have been the content of many sermons. His prayer had been, "Lord, spare the President's life." 45 So too the minister James Hoyt: "In an age noted for the 'Decline of faith,' " Rev. James Hoyt observed, "the Nation had for eleven weeks been literally on its knees before God in prayer for [Garfield's] recovery." 46

"The efficacy of prayer has been made a prominent subject of thought during the past Summer," Washington's Reverend Byron Sunderland noted ${ }^{47}$ and Rev. Robert Collyer said-just before President Garfield's death-that if the President should die "there would at once spring up a vast amount of prayer." W8 When the President

See Mayock v. Martin, 157 Conn. 56, 245 A.2d 574 (1968) (discussing false beliefs in relation to self-mutiliation). Cf. Origen, The Russian Skoptsi.

43. See, e.g., The Sermon of James S. Hoyt, Sept. 25, 1881 (hereinafter James Hoyt Sermon). (1881).

44. R. Conwell, Life, Speeches, and Public Service of James Garfield 352

45. The New York Times, Aug. 29, 1881, at 8 col. 2.

46. James Hoyt Sermon, supra note 43.

47. See B. Sunderland, The Problem of Prayer and the Death of President GARFIELD, A Discourse 3 (1881). Sunderland was, as far as he knew "the only minister who saw and spoke with [the President] after he was shot." Id. Many sermons addressed the religious meaning of the tragedy. For a summary of the responses of the clergy, see ROSENBERG, supra note 1 , at 7.8 .

48. Collyer, quoted in The New York Times, Sept. 18, 1881, at 7 col. 4 . 
died in September it seemed that the prayers had been futile. Even the New York Times addressed the issue of disappointed faith: "Much of the hope which has sustained the people during these weeks of painful suspense," The Times said, "has been due to a certain faith that what seemed to them in every way best for the Nation would somehow be brought about." ${ }^{49}$ The result was different than they had prayed for. "[I]n spite of hopes and fears and the fervent prayers that have risen from so many altars and hearthstones," The Times continued, "the Power that doeth all things well has laid this great disappointment upon the people. If it is a trial of their faith, it is a severe one, but there is nothing in it to weaken their confidence that after all the Nation is in the keeping of a higher power."so

Thus, it was to a nation which included many who were concerned generally about science and religion and about the failure of their prayers that Guiteau addressed his defense.

Specifically, of course, Guiteau addressed his argument to a jury. ${ }^{51}$ While we cannot know about the thought processes of the jury as they listened to the evidence in the Guiteau trial, or what they thought when they came to their decision, we can know something about the orientations, and particularly religious orientations which they brought to the trial.

Here, then, is a summary of the religious beliefs of the jury as given in their responses to the attorneys questioning them to establish their suitability as jurors: John P. Hamlin, in the restaurant business, had not been a member of any church since "quite a young man." When asked if he believed in any of the ordinary usual Christian dogmas or tenets he said, "I did when I attended them, but I have not attended them lately. I was baptized in the Presbyterian Church."s2

\footnotetext{
49. The New York Times, Sept. 20, 1881, at 1 col. 2.

50. Id.

51. As already noted, the jurors chosen said they did not hold infidel views. Guiteau had been, of course, interested in the selection of the jury. Professor Rosenberg notes that among Guiteau's proposed questions of prospective jurors (part of a list which he gave to his brotherin-law, Scoville, who was then defending him), were the following: "Do you believe in the Bible? Do you believe in the letter of the Bible or simply its spirit? Are you now or have you ever been a Christian? Do you believe in the inspiration of Paul and the Evangelists?" Guiteau urged Scoville to pursue the religious convictions of the prospective jurors, to ask whether they believed in the story of creation, Noah and the flood, Abraham and Isaac, the children and the fiery furnace. Rosenberg supra note 1, at 114-15. Scoville asked generally about infidelity, future rewards and punishments and church memberships. 1 Trial, supra note 1 , at $23,31, .75$.

52. 1 Trial, supro note 1 , at 29.
} 
The cigar manufacturer Frederick Brandenberg was a member of the Lutheran Church. He said: "Yes, I think so" when asked if he believed in religious tenets. ${ }^{53}$ Henry Bright, retired, was not an infidel and believed "In Christ and Him crucified." When asked: "You do not believe that this world is the end of all this and that people come by chance and go by chance, do you?" He said "No."54 Charles Stewart, who was a dealer in flour and feed, was a church member. ${ }^{5 s}$

The grocer Thomas Langley was a church member, and had been one for forty years. ${ }^{56}$ Michael Shehan, a grocer, a native of Ireland and a naturalized citizen, was a church member. ${ }^{57}$ S.F. Hobbs, a plasterer, was a church member. ${ }^{58}$ George Gates, a machinist, was not a member of a church but said that he believed in the doctrines of the Christian religion and was not an infidel. ${ }^{59}$ Ralph Wormley, a plasterer, was first not "exactly" a church member, and then never was a church member, but he believed in the hereafter and in heaven and hell. ${ }^{60}$ William Brawner, a merchant (grocery and commission business) was not a church member. He believed in rewards and punishments. ${ }^{61}$ Thomas Heimeline, mechanic, believed in a Supreme being. ${ }^{62}$ Joseph Peather, commission merchant, called himself a Christian. ${ }^{63}$ When asked, these men said that they were not spiritualists or infidels. They, finally, would judge the issues involved in Guiteau's argument.

\section{GuITEAu's DefENSE}

Q. [The defense is] that you are legally insane, and not in fact insane, is it?

A. The defense is, sir, that it was the Deity's act and not mine, and He will take care of it.

Q. Are you insane at all?-

A. A great many people think I am very badly insane. ...

Q. You told the jury you were not insane.

A. I am not an expert. Let the experts and the jury decide

53. Id. at 31 .

54. Id. at 35 .

55. Id.

56. Id. at 37.

57. Id. at 53 .

58. Id.

59. Id. at 66 .

60. Id. at 75 .

61. Id. at 83 .

62. Id. at 95 .

63. Id. 
whether I am insane or not; that is what they are here for. [Guiteau Trial] ${ }^{64}$

We are left with words on the page to evoke the atmosphere of the Guiteau trial, and like any text, the Guiteau trial may mean different things to different readers. The emphasis, tempo, inflection, may all be varied to provide different readings, ${ }^{65}$ and Guiteau's remarks may be seen as symptoms or as argument. ${ }^{66}$ They are taken here as argument. Guiteau appeared at his trial in the role of additional and informal counsel and for a good part of the trial sat at the counsel table. His ideas are thus to be found not only in his formal testimony, but also in his regular interruptions of the proceedings and his comments at the opening of the session each day.

The question of whether Guiteau should have been allowed to speak at all, and whether he was in fact aided by his participation, was the subject of considerable contemporary discussion. The neurologist Dr. George Beard suggested that if Guiteau had kept quiet in court at least "some of the jury might have brought in a verdict in accordance with the evidence" that he was insane. ${ }^{67}$ But Judge Walter Cox ${ }^{68}$ concluded very early that it was best that Guiteau not be silenced. As it was, a writer evaluating the trial in 1904 would see the event, widely viewed as an embarrassment at the time, as one of which the nation could be proud. The trial of Guiteau for the assassination of Garfield, E. Hilton Jackson remarked with some satisfaction, "furnishes a remarkable illustration of the genius and spirit of our Government."69 Guiteau was "without friends and without money." Still, he was "defended by eminent counsel, demanding the full protection of the law and of every guarantee of the Constitution, [and] was accorded every right that could be extended to the most distinguished defendant."70

Medical commentators on the trial found Guiteau's behavior in-

64. Id. at 691 .

65. The text in itself is largely bare though occasionally we see an explicit stage direction. For example, at times the trial record notes that the prisoner spoke "[e]xcitedly," Id. at 136; or that the judge spoke "solemnly," Id. at 2420.

66. Cf. R.D. Laing, The Divided Self 29-31 (1969) (discussing E. Kraepelin's interview with a patient).

67. Beard, The Case of Guiteau-A Psychological Study, 9 J. OF NeRvous AND MENTAL Disease 1, 24 (1882).

68. Judge Walter Cox, born in 1826, practiced law until 1879 when he was appointed to the Supreme Court of Washington, D.C. In the course of his career he taught law at Columbia University (Washington) and published Lessons in Law for Women (1900). as well as a discussion on efforts to obtain a code of law for the District of Columbia, D.C. He died in 1902 in Washington. [See I WhO WAS WhO IN AMERICA 1897-1942 (1966)].

69. Jackson, The Trial of Guiteau, 9 VA. LAW REV. 1023, 1023 (1904).

70. Id. 
dicative either of the man's character or of his insanity. Thus, Dr. Charles Folsom, of Boston's McLean's Asylum and Harvard, wrote in the American Law Review that "[I]t is evident to one watching the trial that Guiteau is either absorbed in the self-satisfied notoriety for which he has yearned all his life, or that in his insanity he entirely fails to appreciate the real gravity of his case." 71 Dr. Folsom noted that Guiteau's "witty remarks," "impertinent jibes," "ready rejoinders," "quick perception of points," "extraordinary memory," "irrepressible gabbing," and "fearless, reckless behavior," suggested either "his intent on having as much fun as possible before his death, or his irresponsibility."72 As Dr. Folsom saw it, Guiteau had "constantly injured his own case, by accusing his brother of being a defaulter in open court; by calling his own witnesses liars; by asking for money for his defense from those who gave to the fund for the widow whose husband he assassinated; and by going off into all sorts of rambling advice to the government to suppress Mormonism, or to President Arthur to appoint or remove this or that officer, on the ground that he can properly direct the man whom he made President." to Dr. Folsom that a sane man, on trial for his life, would hardly have been so heedless of his real position.

The English alienist, Dr. William Ireland, suggested that Guiteau's comments "showed the odious features of Guiteau's character, his monstrous egotism, his misplaced vanity, his petulance and ingratitude." "The prisoner said he was confident that the Deity would take care of him," Ireland wrote of Guiteau some years after the trial. "He kept up a desultory series of remarks and comments upon what was said in, and sometimes out of, Court." While Guiteau's interventions sometimes showed a shrewd view of the bearings of the case in point, and great readiness of retort, Dr. Ireland conceded, "at other times they seemed but the expression of wounded vanity and blind anger." 74

The trial of Guiteau was strikingly theatrical and immensely interesting to the public. Because Charles Guiteau considered himself to be in the counsel role, the defense of the assassin was, as Professor Rosenberg noted in his study of the Guiteau trial, "conducted on two levels, one peculiar to Guiteau, the other corresponding to the perceptions of the other participants." It was, Professor Rosenberg writes,

71. Folsom, The Responsibility of Guiteau, 16 AM. L. REV. 85, 77 (1882).

72. Id. at 97.

73. Id.

74. Ireland, supra note 13 , at 188. 
the "intricate interweaving of these two aspects," the combination of the "delusional and real," which tended to produce the "quality of pathetic grotesquerie" 75 which marked the trial.

There were, certainly, two different insanity defenses offered. George Scoville, Guiteau's brother-in-law and counsel, argued the traditional insanity defense, often stressing hereditary insanity. Guiteau's defense had a different thrust. He claimed his insanity was "Abrahamic insanity," for which he should be acquitted. "The prosecution," Guiteau said to the jury,

pretend I am a wicked man. Mr. Scoville and Mr. Reed say I am a lunatic. I certainly was a lunatic on July 2 when I fired on the President, and the American people generally think I was, and I presume you think I was.... You must say by your verdict sane or insane at the moment I fired that shot. If you have any doubt of my sanity at that moment you must give me the benefit of the doubt and acquit, i.e., if you have any doubt whether I fired that shot on my own account, or as the agent of the Deity. If I fired [the shot] on my own account I was sane. If I fired it, supposing myself the agent of the Deity I was insane, and you must acquit. ... Why did He inspire me in preference to some one else? Because I had the brains and nerve, probably, to do the work. The Lord does not employ incompetent persons to serve Him. He uses the best material He can find. This pressure destroyed my free agency. The Deity compelled me to do the act, just as a highwayman compels a man to give him money, after placing a pistol at his victim's head. The victim may know it is absolutely wrong for him to give money that his wife and child need, but how can he keep it with a pistol at his head? His free agency is destroyed and he gives his money to save his life ... In shooting the President I deny that I violated any law, human or divine. Nothing that the Deity directs a man to do can violate any law. ${ }^{76}$

\section{Guiteau ended on the following note:}

I beg, for your own sakes, and for the sake of the American people, and for the sake of generations yet unborn, that you let this case alone. You cannot afford to touch it. Let your verdict be that it was the Deity's act, not mine. When the President was shot his Cabinet telegraphed to foreign nations that it was the act of a "madman," and it will be far better every way that it be officially

75. ROSENBERG, supra note 1 , at 85 .

76. 2 Trial, supra note 1 , at 2202-05. 
decided that it was the act of a "madman."

Guiteau's speech to the jury marked by intensity and at one point by crying, ${ }^{78}$ was not, on the whole, well received by the public. "Saturday the assassin addressed the jury in his own behalf" The Christian Advocate reported, "reading his speech as published in the newspapers last Monday, his egotism having prompted him to furnish it for publication in advance. In a declamatory manner he rolled forth his sentences, holding the paper with one hand and with the other gesticulating and emphasizing his utterances." Guiteau's speech was a "rambling, illogical affair," the paper said, "abounding in declarations that he was insane when he shot the President, but sane before and since. Of legitimate argument the speech was entirely wanting. Its delivery will scarcely aid him in his desperate fight for life." Judge Cox himself at one point in the trial characterized Guiteau's declarations as "lawless babble," ${ }^{80}$ and it is possible to see the closing speech as nothing more than this.

Yet surely it is also possible to see the argument in the speech, as suggested by the quotation marks around the word "madman." The issue for Guiteau was simple: God was beyond doubt responsible for the death of Garfield. A ram had been sent once, but not this time. Thus, when Guiteau was asked by J.M. Buckley of The Christian Advocate, "What would have been your view of God's relation to the tragedy if President Garfield had got well?" Guiteau answered: "Why, of course, I should have thought that God had countermanded the order. That is what he did in Abraham's case, and Jonah's; he said that Nineveh was to be destroyed, but it was not." Since "the whole American people were praying for their president," Guiteau said, "[there were] millions of prayers, all the Churches and peopleand if he had got well, I should have said that God countermanded the order in answer to all those prayers." 81

Thus Guiteau's invocation of the insanity defense was deliberate,

77. Id. at 2226. Guiteau's remarks to the jury were delivered at some length. He thought of the speech as an oration comparable to those of Cicero.

There had been some discussion at the trial about whether the defendant should be permitted to address the jury, but finally permission was granted, in part on the theory that it was only proper that a man on trial should be allowed to address the jury which would decide the question.

78. Id. at 2224 .

79. Christian Advocate, Jan. 26, 1882.

80. 2 Trial, supra note 1 at 2331 (commenting particularly on Guiteau's repeated claim that public opinion was in his favor).

81. Buckley, $A$ Study of Guiteau, Christian ADvocate, January 12, 1882, at 18. Guiteau made the same point at the trial. I Trial, supra note 1, at 1094. 
and at least to a point, manipulative, ${ }^{82}$ a plea of insanity made in order to achieve a legal result. In this respect, Guiteau seemed unlike those who denied their own insanity and even refused to plead in-

82. Not only was Guiteau informed of the details of the insanity defense, but there was evidence that Guiteau's information extended to the possibility of ultimate release following an official inquiry on his sanity ("Sensation"). 2 Trial, supra note 1, at 1427. Thus it was thought by some, including psychiatrist John Gray, that Guiteau was acting a role. One must note however that this acting, if it was that, did not extend to any claim of an immediate or direct sensory experience.

John Gray, head of the Insane Asylum at Utica, New York, was the major voice of the American Journal of Insanity, a journal formally edited by the "medical officers of the New York State Lunatic Asylum" at Utica. [On Gray, see Waldinger, Sleep of Reason: John P. Gray and the Challenge of Moral Insanity, 34 JOURNAL OF THE HISTORY OF MEDICINE AND AlLIED SCIENCES 163 (1979)]; for Gray on Guiteau, see below infra note. See also E. DWYER, HOMES FOR THE MAD (1987).

Gray's view of the "Abrahamic insanity" argument is suggested by his comment on the testimony of another psychiatrist: "The parallels attempted to be set up by counsel for the defense as to the case of Abraham are altogether aside from any modern transaction; for the whole ancient record must be taken into account and its authenticity granted. The history is one of supernatural interference and visibly so; and therefore furnishes no warrant for any modern parallel." Gray, The Guiteau Trial, supra note 1, at 361 (commenting on testimony 2 Trial, supra note 1, at 1337).

See also Rosenberg, supra note 1; Grod, Mental Illness and AMERICAN Society, 1875-1940 (1983); N. DaIN, CoNCEPTS OF INSANITY IN THE UNITED STATES 1789-1825 (1964).

Guiteau argued both his belief in his inspiration and the truth of his inspiration Gray quoted Guiteau as follows: " $\ldots$. if I could establish the fact before a jury that I believed the killing was an inspired act, I could not be held responsible before the law." (He paused a moment, and then added): "You may add this, that the responsibility lies on the Deity, and not on me, and that in law, is insanity." 1 Trial, supra note 1, at 12 . When Guiteau was crossexamined by Prosecutor Judge John Porter he insisted that the job of the jury was "to decide whether the Deity fired that shot or whether I did it of my own personal act." Id. at 623 . The insanity defense is not prominent in this exchange, which states the issue as one of human versus divine action and responsibility. That, Guiteau is saying, is the issue to be decided. Sometimes, however, "belief" as insanity does stand alone as an issue, as when Judge Porter said that the case came down to the question whether the assassin "believed that he was commanded by God to murder the President" and Guiteau agreed that was "all there is to it." See also 2 Trial, supra note 1, at 1321. A doctor testified that he had some cases involving people who had "attempted murder under the insane delusion that they had instructions from the Lord." Guiteau responded ("sneeringly"): "You know whether I had, don't you?" Was Guiteau referring to the delusions? The instructions?

One can, of course, read these comments as nothing more than Guiteau's deliberate attempt at his trial to convince the jury that he believed in the fact of his own inspiration, perhaps as evidence of his own continuing insanity (despite his usual claim that he was sane at his trial). But this seems to read out the "as ifs" in the argument on his insanity at the time of the assassination. And why, if he was sanely manipulative of the insanity defense, did he fail to claim to hear voices? This, as much of any problem relating to the timing of the inspiration (see Gaylord, 36), would seem to have been a strategic miscalculation. In his preliminary report on Guiteau's sanity (to determine whether Guiteau should stand trial or be sent to a hospital) psychiatrist John Gray quoted Guiteau as saying that "if the jury accepts this [inspiration] as my belief, and if the jury believes as I believe, that the removal of the President was an inspired act and therefore not my own act, they are bound to acquit me on the ground of insanity. I have looked over the field carefully." 1 Trial, supra note 1, at 12 (opinion of John Gray). 
sanity. ${ }^{83}$ But it is clear that while Guiteau asserted his legal insanity, he denied his actual insanity. Moreover, the "as if insane" argument Guiteau offered, far from being incoherent, resonated in the culture to which it was addressed and was offered in a language entirely familiar to his audience. The jury knew what it meant for Guiteau to say that he was like Abraham and must have understood that Guiteau's defense often involved the idea that the jury should accept not only his belief in a divine command but the fact itself. "There are two kinds of insanity," Guiteau said, "Cranky insanity and Abraham's style of insanity. I belong to Abraham's style of insanity." He challenged an expert witness: "What do you think about Abraham, doctor? He is my example. That is the school I belong to."B4

Guiteau's was the language his audience had been taught as children. James Bryce, in The American Commonwealth (1889) wrote

A great deal of the ordinary reading of the average family has a religious tinge, being supplied in religious or semi-religious weekly and monthly magazines. In many parts of the West, the old problems of predestination, reprobation, and election continue to be discussed by farmers and shopkeepers in their leisure moments with the old eagerness, and give a somber tinge to their views of religion. The ordinary man knows the Bible better, and takes up an allusion to it more quickly than the ordinary Englishman, though perhaps not better than the ordinary Scotchman."85

The "Ordinary Man" may or may not have been to school. But those who did get to school often went to schools which reinforced a Christian heritage. Loosely speaking, school books used in the first half of the nineteenth century formed the background of thinking and development of children who were adults in the second half of the nineteenth century. Professor Ruth Miller Elson's study of 19th century American school books notes that "school books before the Civil War accept without question the Biblical history of the world and the creation of man. The Garden of Eden and its inhabitants are as real

83. See discussion of Freeman, infra, text accompanying notes 115-150.

84. 2 Trial, supra note 1, at 1415. Guiteau often asked the experts to deal with Abraham. See id. at 1415, 1416, 1418, 1429, 1439, 1452, 1467, 1483, 1537, 1617, 1633, 1641, 1643, 1922, 2137. One expert testified that Abraham was not insane because there was no disease of the mind. Id. at 1340. Scoville said at one point that he "did not care to try Abraham," id. at 1343. The possibility of the insanity of the Apostles was also discussed. Id. at 1345 .

85. J. Bryce, The American Commonwealth 573 (1889). Professor George Marsden notes that "[t]he Bible, it was constantly asserted, was the highest and all-sufficient source of authority." G.M. Marsden, Fundamentalism and American Culture: The Shaping OF THE 20Th CENTURY EVANGELICALISM 1870-1925 16 (1980). 
as the Appalachians." ${ }^{86}$ Professor Elson noted that "Innumerable instances of God's direct interposition in favor of the American people are given to support the idea that Americans are the people chosen by God in the modern world for a special destiny." For example, she writes that, in the textbooks, "Columbus is guided by God through great difficulties; His intervention is not by inspiration but by miracles." And again, the coming of the Pilgrims was "ordained by Providence to reform the world." every school book." 88

Even if the Bible was no longer quite as central to America in the 1880 's as it had been earlier, ${ }^{89}$ it nonetheless provided a pervasive background, accepted or rejected, against which things could be seen and understood. But through the 19th century, the problem of how one approached the Bible was a matter for debate within Christianity. Genesis 22, for example, could be viewed as literally true and centrally relevant to the Christian tradition. Here we have a treatment of Abraham by Bishop Huntington of New York: When God told Abraham that he would have a child, Bishop Huntington said, "no stupid rationalism in him rose up to doubt the glorious word." "When God suddenly required him to take that dearly-loved boy around whose fair head such marvelous hopes had already begun to cluster, and make him ready for a sacrifice, the good man lifted up the burden of this awful sorrow, went to the mount, laid the wood in order, built the altar, and then answered to the child's unsuspecting question, 'Where is the victim?' God, my son, will prepare Himself a burnt-offering. ..."90 The conclusion relates this story, in a manner common for many centuries, to the central Christian narrative. "So, in the eternal purpose of the Spirit, the complete succession of Scriptural events is one plan; the Revelation of Christ, the crucified Redeemer and everlasting Life, is the center and heart of the entire body

86. R. Elson, Guardians of Tradition: American Schoolbooks of the NineTEENTH CENTURY 17 (1964). On late 19th century education, see M. Keller, AfFaIRS OF State: Public Life in Late Nineteenth Century America (1977).

87. Elson, supra note 86 , at 60 .

88. Id. at 61 .

89. See The Bible in America: Essays in Cultural History (N. Hatch \& M. Noll eds. 1982).

90. F. Huntington, Christ in the Christian Year in the Life of Man: Sermons for LAyman's Reading, Trinity to AdVENT 70-71 (1881) (Episcopal Bishop of Central New York). For Huntington on the labor question, see the extract published in $1 \mathrm{~A}$ DocuMENTARY History OF RELIGION IN AMERICA SINCE 1865115 (Gausted ed. 1983). See also Hopkins, The Rise of The Social Gospel in AMERICAN Protestantism 83, 89, 151 (1982). 
of the Bible making it one organized whole. And so even in believing Abraham we behold the victory which overcometh the world, even a Christlike faith."91

But this view of Abraham was not the only one possible: indeed, a leading liberal minister, Theodore Parker, had used the story of Abraham decades earlier as one example of a point at which the Old Testament could simply not be viewed as literally true. Protesting the intellectual climate of his time, Parker wrote that "Matters have come to such a pass," that he is considered "an infidel, if not by implication an atheist, whose reverence for the Most high forbids him to believe that God commanded Abraham to sacrifice his Son." This was, Parker wrote, "a thought at which the flesh creeps with horror; to believe it solely on the authority of an oriental story, written down nobody knows when or by whom, or for what purpose; which may be a poem but cannot be the record of a fact, unless God is the author of confusion and a lie."92 Thus to say "like Abraham" meant different things to different people, even when not used as a justification for the assassination of the President. It will be urged below (Section III) that those different approaches to the biblical story itself are visible in the responses offered in the general culture to individuals who invoked Abraham in justification of their own criminal behavior. Before reaching that issue, however, it is appropriate to consider the response of the legal system to the claim.

\section{Religious Beliefs and InSANe Delusions}

It is not an opinion which I mean to lay down as a rule of law to be applied in all cases, that fanaticism is a proof of unsoundness of mind, but there was in this particular instance, so much religious fanaticism, such great absurdity and extreme folly, that if [the deceased] was now on his trial, it could hardly be said from the evidence, that he could be called in to answer for his criminal acts.

Lord Denman, $\mathrm{CJ}^{93}$

Guiteau's argument raised in an extreme form a large issue of the relationship between religiously motivated behavior and the rules of the legal system. This first argument-which strikes, in effect, above

91. Huntington, supra note 90 , at 71. For an introduction to typology, see P. Sheingorn "Typology and the Teaching of Medieval Drama" in APPROACHES To TEACHING OF MEDIEval ENGlish Drama (R. Emmerson, ed.) (M.L.A. forthcoming).

92. Parker, The Transient and Permanent in Christianity, [1841] in Three Prophets of Liberalism: Channing-Emerson-PARKer 113, 126 (1964).

93. R. v. Tyler \& Price, 8 Car \& P.616 (1838). 
the legal system-was that he had in fact been divinely commanded to kill the President and that this command served as a legal excuse, since the "higher law" must control. ${ }^{94}$ As to this, one must stress the obvious. The center of the Guiteau trial is the certainty of his audience that there had been in fact no divine command to Guiteau to kill the president. ${ }^{95}$ Far from saying that the truth of the divine command to Guiteau, at least, was unknowable, the discussion at the Guiteau trial proceeds on the assumption that the truth was entirely known. Thus, at one point Mr. Reed, defending Guiteau, said that "[n]obody claims that he was inspired to do it. Nobody pretends it. It would have been monstrous to pretend it."96 Only Guiteau himself, Reed said, thought that he had been inspired. And again, "not that he was inspired or that God did it, by no means; but the evidence of insanity is the belief that God inspired him to do it. That proves his insanity." 97 A witness was asked by defense counsel Scoville, "Do you believe at all in the Deity's inspiring people to do acts at the present day?," and he answered, "not of that character." The audience applauded. ${ }^{98}$ Because of this certainty, it was not necessary to reach either the question of the effect that such a command, if given in fact, might have on the general legal rule, or the question of how one could

94. But perhaps the higher law is that the human law controls. The point that the relationship between higher law and human law is not simple is suggested with notable economy in Melville's comparison between Captain Vere and Abraham in BILLY BuDD (Chapter 22). See also J. Stephen, A History of The Criminal LAW of England at $160 \mathrm{n} .1$ (1883): "If a special Divine order were given to a man to commit murder, I should certainly hang him for it unless I got a special Divine order not to hang him." (And would he then still be functioning as a judge?).

For discussions of problems relating to divine command, see J. IDZIAK, DIVINE COMmand Morality: Historical and Contemporary Readings (1979); P. QuinN, Divine Commands and Moral Requirements (1978); Divine Commands and Morality (P. Helm, ed. 1981).

95. Persons claiming direct revelation were, and much earlier than the nineteenth century, viewed with distinct suspicion. As to the historical evolution of the revelation issue, Keith Thomas writes: "In the later seventeenth century it became orthodox to declare that the gift of prophecy had ceased .... The change may be best expressed by saying that in the sixteenth century the claims of a would-be prophet would always be seriously investigated, even if ultimately exposed as groundless, but by the eighteenth century the majority of educated men concurred in dismissing them a priori as inherently ridiculous." K. THOMAS, REL1GION AND THE DECLINE OF MAGIC 145-46 (1971). James Moorhead has observed that "by the late nineteenth century [evangelical] picty was waning" and that this change was symbolized by a deemphasis on the sudden dramatic conversion experience. "Distrustful of sharp discontinuities in the spiritual life, many Protestants preferred to speak of continuous maturation and of the natural unfolding of religious experience." Moorhead, The Erosion of Post Millenialism in American Religious Thought 1865-1925, 53(1) CHURCH HisTORY 61, 68-69 (1984).

96. 2 Trial, supra note 1 , at 1979.

97. Id.

98. Id. at 1337. 
determine whether such a command had been given to Guiteau or anyone, now or ever.

The consensus reflected in trial as to this fundamental issue of the fact of the command ${ }^{99}$ meant that the problem could become whether Guiteau's belief in this delusion-if he believed in it at allwould be classified as a delusion which excused criminal behavior. The positive law on religion and the insanity defense can be quickly stated. If the defendant's religious belief were to be classified as an "insane delusion," he might be protected by the insanity defense. ${ }^{100}$ Divine command was well known as an example of such a delusion. If on the other hand the belief was not classified as insanity, it would be seen merely as extreme religious belief. A few years before the Guiteau trial such extreme religious belief had come before the Supreme Court of the United States in a case involving Mormon polygamy. ${ }^{101}$ In January, 1879, the United States Supreme Court delivered its opinion in Reynolds $v$. United States, a case dealing with the prosecution of a Mormon polygamist under the 1862 federal anti-bigamy statute. A standard citation in the field of church and state, Reynolds upheld the conviction and rejected a first amendment free exercise defense. In Reynolds, the jury had been instructed that:

99. Other parts of the law might also reveal doctrinal civil religion. Simon Greenleaf's nineteenth century treatise on Evidence contains a telling discussion of the incompetency as witnesses of those who are "insensible to the obligations of an oath, from a defect of religious sentiment and belief." American law, he writes, "presumes that every man brought up in a Christian land, where God is generally acknowledged, does believe in Him and fear Him. S. Greenleaf, The Law of Evidence, Part III Sec 368, 370.

See R. Bellah, The Broken Covenant: "It is one of the oldest of sociological generalizations that any coherent and viable society rests on a common set of moral understandings about good and bad, right and wrong, in the realm of individual and social action. It is almost as widely held that these common moral understandings must also in turn rest upon a common set of religious understandings that provide a picture of the universe in terms of which the moral understandings make sense."

The issue of direct inspiration is evident in the case of Anne Hutchinson, see "The examination of Mrs. Anne Hutchinson" in THE ANTINOMIAN CONTROVERSY n.29 (Hall ed. 1968), as well as that of the 19th century Mormons. See the Mormon letter quoted by William James in VARIETIES OF RELIGIOUS EXPERIENCE 365 (1958). It may be noted that modern revelation is one of the doctrines of Mormonism. See also Cover, The Supreme Court 1982 Term: Foreword: Nomos and Narrative, 97 HARVARD L. REV. 4 (1983) (problem of new revelation in systems based on revelation).

The positive law as it relates to divine command or any other explicitly religious issue may simply be whatever the law wants it to be. See J. ThaYer, Legal EsSaYs 325 (1927).

100. On the history of the insanity defense, see $1 \mathrm{~N}$. WALKER, CRIME AND INSANITY in England: The Historical Perspective (1968). On the insanity defense in general, see A. Goldstein, The Insanity Defense (1967); H. Fingarette, The Meaning of Criminal INSANITY (1972). There is, of course, no attempt here to discuss the modern debate over issues relating to excuse for criminal responsibility.

101. Reynolds v. United States, 98 U.S. 145 (1879). 
... if the defendant, under the influence of a religious belief that it was right,- - under an inspiration, if you please, that it was right,deliberately married a second time, having a first wife living, the want of consciousness of evil intent, the want of understanding that he was committing a crime, did not excuse him. ${ }^{102}$

Upholding the instruction, the Court by Chief Justice Morrison Waite noted that: "[L]aws are made for the government of actions, and while they cannot interfere with mere religious belief and opinions, they may with practices." Even if one "believed that human sacrifices were a necessary part of religious worship,: could it really be argued that the state could not prevent this? Or, if a wife religiously believed it was her duty to burn herself upon the funeral pyre of her dead husband," he continued, "would it be beyond the power of the civil government to prevent her carrying her belief into practice?" So, here, Justice Waite concluded, where plural marriages are forbidden, "can a man excuse his practice to the contrary because of his religious belief?" The answer was clearly no, for "to permit this would be to make the professed doctrines of religious belief superior to the law of the land." In effect, this would "permit every citizen to become a law unto himself," and then "Government could exist only in name. ..."103

The principle of the Reynolds case is that religious belief provides no excuse from the general law. There is no need under Reynolds, to focus on issues of sincerity, since sincere or not, the belief could not excuse. An essential legal idea in the Guiteau trial was that the rule of Reynolds would govern Guiteau's act unless his religious "beliefs" would be judged an "insane delusion." 104

The insanity defense assumes not only that the insane should not be considered criminals, but also that one can know who the insane are. ${ }^{105}$ Nineteenth century America was aware of change on that is-

102. Id. at 162. John Locke in A Letter Concerning Toleration had made the fundamental argument:

You will say by this rule, if some congregations should have a mind to sacrifice infants, or (as the primitive Christians were falsely accused), lustfully pollute themselves in promiscuous uncleanliness, or practice any other such heinous enormities, is the magistrate obliged to tolerate them because they are committed in a religious assembly? I answer, no. These things are not lawful in the ordinary course of life, nor in any private house; and therefore, neither are they so in the worship of God, or in any religious meeting.

103. Id. at 166-167.

104. See arguments of the prosecution 2 Trial, supra note 1 at $1755,1919,1832$.

105. "If sanity and insanity exist, how shall we know them? The question is neither capricious nor itself insane. However, much we may be personally convinced that we can tell the normal from the abnormal, the evidence is simply not compelling ... [n]otions of normality 
sue. "You know as a matter of history," a Pennsylvania court noted in 1878, "that men were not insane in the old times without they were madmen. A man was not considered insane if he knew what he was doing. He must tear his clothes, do acts of violence-and continuously do all of those things which indicated all the time that he was crazy. ..."106

This extreme behavior was no longer required by law, though a large question remained open as to what exactly was required.

The M'Naghten formula relates to the capacity to know right and wrong, and it was this traditional formula which was used in Guiteau's case. ${ }^{107}$ Judge Cox's general instruction to the jury was to the effect that a criminal is responsible if "he knew what he was doing and knew that what he was doing was contrary to the law of the Land." This was true unless the criminal "was laboring under such a defect of reason as to be incapable of understanding the obligation of the law of the Land and the duty and necessity of obedience to it, and of understanding that his act was wrong because it was in violation of the law of the Land." 108 Thus, Judge Cox told the jury that the test of responsibility was "the question of knowledge of right and wrong as

and abnormality may not be quite as accurate as people believe they are." Rosenhan, On Being Sane in Insane Places, 179 SCIENCE 250, 250 (1973).

It may be that there is a presumption of sanity which stands, whatever one's opinion or mind-sets, until somehow brought into question. One might then ask: What triggers the legal inquiry? And answer it: "a crime," "an eccentric or anti-social act," "a will subject to challenge by a relative." It is only then and only reluctantly, that we are asked to consider whether, for example, a belief in spiritualism makes one unfit to make a will. (See Field, Is Belief in Spiritualism Ever Evidence of Insanity per se?, VI 6 MEdICO-LEGAL J. 194 (1888).

106. Commonwealth v. Lynch, 25 PITT. L.J. 193, 194 (1878).

107. That is, though somewhat critical, Judge Cox used a general statement of the M'Naghten rules. It was said that under the M'Naghten rules one deals with the delusion "as if the fact with regard to which the delusion exists were true." (2 Trial, supra note 1, at 2336). "This has been in part recognized as law in this country," said Judge Cox. He then quoted Lemuel Shaw on the subject of monomania.

See also Commonwealth v. Rogers, 7 MetCalf 500502 (1844) (Shaw, L.J.). See the discussion of the Shaw opinion in DAvis, Homicide IN AMErICAN Fiction, 1798-1860 93 (1957).

This seems to treat the religious delusion (divine command) as one of fact. Cf. ST. J. ROBILLARD, RELIGION AND THE LAW 127 (1983) (suggesting that such a delusion is one of "law" and is not a defense). See also G. Williams, Criminal LaW: Part I 53 46, 98 (1953).

108. 2 Trial, supra note 1, at 2336. The Mormons, while not, of course, arguing the insanity defense, did urge that they lacked the requisite mental state for conviction of a crime. See Brief for Plaintiffs In Error at 55-57, Reynolds v. United States, 98 U.S. 145 (1879) (discussion of mens rea). See supra notes 73-75 and accompanying text.

Judge Cox indicated that the jury could take into account the evidence of hereditary insanity, Guiteau's past life, his behavior at Oneida, and all other facts introduced into evidence which bore on Guiteau's mental state at the time of the crime. 2 Trial, supra note 1 at 2334. 
to the particular act, or rather the capacity to know it." The issue of insane delusion is only important, Judge Cox said, as it throws light upon the question of knowledge of, or capacity to know, right and wrong.

Pursuing the matter of delusion, in his charge to the jury, Judge Cox identified two types of belief, one of which would not involve insanity while the other would. In the case of the first, a belief or delusion based on reason and internal process, the rule would be that of the Mormon polygamy case, Reynolds $v$. United States. ${ }^{109}$ The Mormon prophets were not permitted to violate the law relating to bigamy. In Reynolds $v$. United States, the "professed doctrines of religious belief" could not be allowed to be superior to the law of the land. And here, though "a man might reason himself into a conviction of the expediency and patriotic character of political assassination," one could not "allow him to find shelter from punishment behind the belief, as an insane delusion." 110 If Guiteau's position reduces itself to something like the idea that the death of the President is necessary to accomplish a good object, Judge Cox said, then it is only "one of those vagaries of opinion for which the law has no toleration and which furnishes no excuse whatever for crime." These were sane beliefs. ${ }^{11}$

But there was another kind of belief which was an insane delusion, Judge Cox said. This consisted of "a belief by a person that he is inspired by the Almighty to do something; to kill another, for example-and this delusion may be so strong as to impel him to the commission of a crime." As to this type, "[t]he defendant, in this case, claims that he labored under such a delusion and impulse, or pressure, as he calls it, at the time of the assassination."112

Judge Cox elaborated on the distinction between the two kinds of delusion in the following way: "It is easy to understand that the conceit of being inspired to do an act may be either a sane belief or an insane delusion." In his discussion of sane beliefs, Judge Cox then acknowledged religious convictions and commitments common in American Christianity: "A great many Christians believe" he said "not only that events generally are providentially ordered, but that they themselves receive special providential guidance and illumination in reference to both their inward thoughts and outward actions

109. 98 U.S. 145.

110. 2 Trial, supra note 1 , at 2340 .

111. Id. at 2341.

112. Id. 
and, in an undefined sense, are inspired to pursue a certain course of action." But this "undefined sense" of inspiration is a mere sane belief, Judge Cox said "whether well or ill founded." As against this, "if you were satisfied that a man sincerely though insanely, believed that, like Saul of Tarsus, on his way to Damascus, he had been smitten to the earth, had seen a great light shining around him, had heard a voice from heaven, warning and commanding him, and that thenceforth, in reversal of his whole previous moral bent and mental convictions, he had acted upon this supposed revelation, you would have before you a case of imaginary inspiration amounting to an insane delusion." 113

"[T]he insane delusion," Judge Cox explained, "seems to be an unreasoning and incorrigible belief in the existence of facts which are either impossible absolutely, or, at least, impossible under the circumstances of the individual." Thus, "A man, with no reason for it, believes that another is attempting his life, or that he himself is the owner of untold wealth, or that he has invented something which will revolutionize the world, or that he is President of the United States, or that he is God or Christ, or that he is dead, or that he is immortal, or that he has a glass arm, or that he is pursued by enemies, or that he is inspired by God to do something." Judge Cox made plain that, as he understood it, "the fact believed is something affecting the senses." He stressed that "the important thing is that an insane delusion is never the result of reasoning and reflection. It is not generated by them, and it cannot be dispelled by them." ${ }^{114}$ The responsibility of the jury, said Judge Cox, was to find whether Guiteau's claim presented anything like these descriptions of the insane delusion. ${ }^{115}$

The distinction between a sane belief and an insane religious delusion had been recently illustrated by the 1879 case of Charles Freeman, "the modern Abraham." 116 Freeman killed his young daughter Edith, in May 1879, believing that this sacrifice had been divinely commanded and that the child would rise on the third day. ${ }^{17}$ Free-

113. Id.

114. Id. at 2337 .

115. At least on the issue of auditory and visual hallucinations, it plainly did not. The point here is that unlike Joan of Arc, Guiteau did not hear voices. Nor did he see visions. He did not "get [his] inspirations in that way." 1 Trial, supra note 1, at 617.

Charles Freeman, by contrast, had visions (see supra notes $87-95$ and accompanying text).

116. G. Beard, The Case of Guiteau: A Psychological Study 9 (1882).

117. The Pocasset Tragedy was reported in newspapers as far away as London. See, e.g., London Times, May 5, 1879, at 7 col. 6. After Freeman's acquittal in December, 1883, Dr. Folsom published an article on the case, including a long excerpt from Freeman's testimony at his trial. Folsom, The Case of Charles F. Freeman of Pocasset. Mass. 40 AM. J. InSANITY 353- 
man had consulted his wife and after some deliberation had concluded that this was a test, like the test of Abraham, recounted in Chapter 22 of Genesis. Freeman was found insane on the basis of a hearing held in 1879 and declared unfit for trial. He was in an institution at the time of the Guiteau trial. ${ }^{18}$

Freeman wanted a jury trial. "I could convince any jury that I stand on the top of Mount Zion," he said, "that I hold the keys of heaven, and that I was but obeying God's command." He felt that he had done his duty. "I ought to obey God rather than man." Of course, "we should abide by the common laws as a general rule, and it is not in accordance with Christianity to break human laws." $\mathrm{He}$ would, however, "qualify that by saying that God has special laws in his plans:" 119

Freeman believed that he acted on the evidence of his senses. "Do you believe now that you acted in accordance with the law of God?," he was asked. "Certainly I do," he said, "if I had not had so much supernatural evidence I should not have been here." 120 The evidence which Freeman believed included visions. "Why," said he, "it is just as I look at you now and think I see you. It may be an optical illusion, but if I feel, smell and touch you, and you strike back, I am convinced." 121 And finally Freeman rejected the ideal of his own insanity. "What will become of my past life and teachings," he said, "if I am adjudged insane? Let me go into court and preach." 122

Guiteau's brother-in-law Scoville, offering the argument for the

363 (1884). Materials relating to Freeman's release in 1887 can be found in the Massachusetts State Archive. [Application for release of Charles F. Freeman from the Danvers Insane Hospital, 16 March 1887. Files of the Governor's Council, Box 98 (Archives of the Commonwealth, Boston, Massachusetts).]

118. Freemen was finally tried in 1883. Following his acquittal, Freeman, though then sane, was hospitalized pursuant to the Massachusetts statute of 1873 which provided that a prisoner should be kept in confinement "until it appears to the Governor and Council that he may be discharged and set at large without danger to others." Under this statute there was no issue of treatment and there could be no discharge simply on a finding of sanity. The acquitted individual "is confined in the hospital as a place of detention, because his being at large would be dangerous to the peace and safety of the community." Gleason v. Inhabitants of West Bolyston, 136 Mass. 489, 490 (1884) (citing St. 1862, c. 223, § 17).

Freeman was perhaps thinking of Guiteau (in 1883) when he said "I never aspired to go into politics or hold office and for that reason I do not think it can be said about me that I wished to be a great man and gain notoriety." (quoted in Folsom supra n.117 at 356). After his release in 1887, it is reported that "Freeman went west to begin life anew." Barnstable, Three Centuries of a Cape Cod Town 367 (D. Trayser, ed. 1939).

119. “A Religious Maniac," Boston Daily Advertiser, Jan. 30, 1880, at 1, col. 9.

120. Id.

121. Id.

122. "The Pocasset Child-Murder," Boston Daily Advertiser, Jan. 29, 1880, at 1, col. 5. 
defense in his speech to the jury, reminded the jury of the legally recognized insane delusion of Charles Freeman. Discussing Guiteau's inspiration and how it worked on Guiteau's mind, Scoville said,

What did he do? Consistent with his Christian character, with his education, he prayed to the Lord. You may say, and gentlemen have throughout, that the idea of a man having murder in his heart and praying to the Lord is shocking. The act of an insane mind is usually shocking to the sane mind. Is it more shocking than the act of the mother who knelt in prayer with three children and then killed them? Was it more shocking than the act of Freeman and his wife, near Boston, who knelt in prayer and wrestled in prayer with the Lord to know whether it was His will whether they should kill their sleeping child, and rising from their knees the father proceeded to drive the knife home to the heart of the little girl.

Was not that shocking? It would be in a sane person, but with the insane it is different, gentlemen. ${ }^{123}$

And Freeman seems to appear in Judge Cox's charge to the jury: "Another man, whom you know to be an affectionate father, insists that the Almighty has appeared to him and commanded him to sacrifice his child." 124 This delusion, "which reason cannot touch," is given as an example of the insane delusion which should result in acquittal.

A number of doctors in their discussion of insanity, compared Guiteau favorably and unfavorably with Freeman in assessing the validity of his insanity defense. ${ }^{125}$ Dr. Folsom, who had participated in the Freeman case insisted that Guiteau's arguments were simply a "poor imitation of those features of the case of Freeman, the Pocasset murderer." Writing in the American Law Review on the Guiteau case, Folsom thought that "the theories of inspiration and impulse were only after thoughts, or adopted as means to escape the gallows. . . ."126 Dr. Godding, who discussed Guiteau's inspiration at some length, recalled Freeman of Pocasset, "who prayed to God with his wife, and pondered His Word," until Freeman had "an impression in his mind, that he must offer up his daughter, that his faith might be

123. 2 Trial, supra note 1, at 2121-22. See also 1 Trial supra note 1, at 1341.

124. Id. at 2337-38.

125. The Canadian insurgent Louis Riel (tried for treason and handed in 1885) was, in turn, compared with Guiteau. See THE QUEEN v. Louis RIEL (with an introduction by Desmond Morton) pp. xxix, xxx (1974). See also Ireland, Through the IVORY GATE 229 (1889). I would like to thank Richard Kay for calling the Riel trial to my attention.

126. Folsom, The Responsibility of Guiteau, 16 AM. L. REv. 85, 95 (1882). Dr. Folsom was convinced of Guiteau's insanity on other grounds, and was a witness for the defense, 1 Trial, supra note 1, at 770 . 
manifest to the world, believing that God was able to bring back life to that cold clay on the third morning." 127 Dr. Denny found that "there was a similarity in the case of Guiteau and Freeman, in some ways," particularly "the suddenness of conception" (or rather the way they expressed. themselves about it); also "the way they had struggled against the desire and the fixedness of the idea." And then he added, "the deed itself showed insanity." 28

Other commentators on the Guiteau case also remembered Freeman. The liberal clergyman, Moncure Conway, in his remarks on Garfield's assassination and the influence of religion and others also referred to the Pocasset case. Conway noted that, "[T]his is the second time in the last few years, that America has been brought face to face with some of the possible results of preserving the forms and phrases of barbarian religion." 129 The journalist Gail Hamilton recalled Freeman, the man "who slew his own child, his helpless, innocent, baby-daughter, in alleged obedience to voice from Heaven." Religion, she said, "justly refused to be held responsible for his crime, but she came a great deal nearer to the Pocasset murder than ever came our civil service to the Washington assassination."130 And free thinker Robert Ingersoll remembered Freeman as one who "imitated Abraham; and, for that matter Jehovah himself." In the history of Christianity, Ingersoll said, there are "thousands and thousands of

127. W. Godding, Two Hard Cases: Sketches from a Physician's Portfolio 177 (1882). Godding's views are summarized in RosenBERG, supro note 1, at 134-35. Godding viewed Freeman as having merely "an impression" (as opposed to visions). Godding, supra at 177.

128. Reports of Societies, 107 Boston Medical \& Surgical J. (Decembet 28, 1882).

129. M. Conway, The Life and Death of Garfield: A Discourse Before the South Place Religious Society 18 (1881).

130. Hamilton, The Things Which Remain, 135 NORTH AMERICAN REv. 76, 78 (July, 1882). Gail Hamilton, denying that the assassination was the fruit of the spoils system, raised the possible responsibility of the family ("for Guiteau sprang, full-armed for vice, from the bosom of a once responsible family") and religion ("for Guiteau was a Christian before he was a politician and after he was an assassin"). Id. Essentially Hamilton argued that Guiteau was not the fruit of any "political or religious or political system whatever." Hamilton, at 80 . The Freeman case raised familiar questions as to whether religion was a cause of insanity, and familiar denials of the charge. When, as in Freeman's case, the insanity was associated with murder, the relation of religion and insanity would be discussed with peculiar intensity. "The Massachusetts tragedy of the Freemans has sent a thrill of horror through the land," one journal commented, and, "as usual, some indignant writers have ascribed the murder of the little child to the effects of religious fanaticism." There were others, "more precise, but equally wrong-headed," who attributed the murder "to the peculiar tenets of the Second Adventists." But both of these are unjust, the journal insisted. "There is no connection between religious enthusiasm and infanticide. There is nothing in the belief that the day of the Lord's coming is at hand, or even in the delusion that the time has been revealed in prophecy, to move parents to kill their child." (The Churchman, May 24, 1879, at 562, col. 2-3.) 
such instances, and there will probably be many thousands more ... produced by throwing away our own reason and taking the word of some one else- often a word that we do not understand." 131

Finally, the law found Freeman insane. But there were also those who thought that Freeman should be hanged for the murder of his daughter. For some, Freeman was not a madman but only a fanatic, whose beliefs had led him to commit a terrible crime for which he should be punished. "We see no sign of insanity," the Independent said of Freeman in 1879. Rather, "[i]t was somehow impressed on the man's mind that the sacrifice was needed. He somehow took it to be the direction of God."132 There are, the Independent noted, "Many men [who] think God 'directs' them to do what is only selfevolved; but we do not call them crazy." Freeman was no more crazy than another man who believes that God impresses it on his mind that he should go or not go on a certain vessel. The only difference is that this is an exceptional case of such impression, in which the horror of it did not correct it."133

Viewed in this light the issue then became purely a matter for the criminal law. "What then shall we do with murderous fanatics? Shall a man who commits murder, or adultery, or robbery, supposing it to be an injunction of God, be punished according to law?"134 Clearly yes, since the purpose of the criminal law is to "protect the rights of the community." This was also true, the Independent noted, in "the parallel case of the Mormon or the Oneida adulteries." "135 In all these instances, "the punishment should be for the offense, without regard

131. THE WORKS OF Robert G. INGERSOLL 104 (Dresden ed. 1900).

132. The Pocasset Murder, The Independent, May 15, 1879.

133. Id.

134. Id. The Independent suggested that after the sentence, Freeman might be imprisoned for life instead of being hanged.

135. Id. On Oneida see C. Weisbrod, The Boundaries of Utopia (1980); Weisbrod, On the Break Up of Oneida, 14 CoNN. L. REv. 717 (1982); and works cited therein. There were many references to Oneida at the trial, see, e.g., 2 Trial, supra note 1, at 2145 (Scoville), and testimony concerning Guiteau at Oneida was submitted by the aged J.H. Noyes. See also The Lesson of President Garfield's Assassination, 6 AM. CATH. Q. REv. 683, 689 (1888) (discussing Oneida and Mormons, stating that "Conscience cannot be altogether deadened and to silence it, men invent religions to justify criminal deeds").

George Beard believed that, "While the mere going to the Oneida Community was not in itself a proof of insanity, yet for an energetic, able, and ambitious man to leave his studies and break up all his planned of life, exile himself from home and friends and rush to this society, was as immoral and frantic an act as could well be committed. ..." G. BEARD, THE CASE OF Guiteau-A Psychological Study 25 (1882).

The English psychiatrist John Bucknill, recalling the fact that Guiteau's father was a follower of Noyes, suggested that "probably it would not be too much to say that the assassination of President Garfield was the outcome of Oneida" (1882-1883). Bucknill, The Plea of 
to the intent."136

The state's response to the Pocasset murder illustrates one point which is entirely consistent with the general impression we have of Guiteau's execution as the response of an outraged nation to a Presidential assassination. At least in a case which did not involve a regicide (and which did involve sensory delusions) the law of insanity in late 19th century America could perfectly well understand that an insane delusion of divine command might serve as a basis for the legal insanity. ${ }^{137}$ Two other points, perhaps less obvious, are also suggested. First, even in a case like that of Charles Freeman, some people saw fanaticism and not insanity, and insisted that punishment was the appropriate response of the state. Even the conclusion that Freeman was insane, in short, was not altogether obvious. Second, a large question relating to the debate over the authenticity of biblical religion might be opened by one's approach to cases like that of Freeman or Guiteau. Even those who agreed that there had been in fact no divine command to kill might disagree to a troublesome extent about why they thought so.

\section{A State Trial in Christendom}

Kings, as we think, are made by men. Jurors, according to our

Insanity in the Case of Charles Guiteau, 39 AMERICAN JOURNAL OF INSANITY 181, 197 (18821883).

Gray thought that the time at Oneida was "doubtless the turning point" of Guiteau's life. Gray wrote "It showed itself in an awful perversion of intellectual activity and misdirected religious thought, which shattered to fragments all the moral sanctions of human law, and all the sacred institutions of civil society, with all the guarantees of personal accountability, and made him the sport of an unbridled egotism by self-delusions, though a pretense of individual union with the Divine will and Divine authority ...." Gray, The Guiteau Trial, supra note 1, at 312 .

136. The Pocasset Murder. The Independent May 15, 1879.

137. The insanity defense in the Freeman case was analyzed just after the events in the ALBANY LAW JOURNAL: In sacrificing his daughter, "Freeman apparently considered that he was acting under the direct command of God as revealed to him in dreams and visions." If the sanity defense was used the "jury must be instructed to find according to the 'right and wrong' test in The McNaughten's (sic) case." The journal also cited Commonwealth v. Rogers on monomania. Stone, Legal Aspects of the Pocasset Affair, X AlbaNy LAw J. 71 (1879). In terms of the legal test of insanity often referred to as the right/wrong test, there is an ambiguity in the word "wrong" as used in the formal statement of the rule. The problem was summarized by James Fitzjames Stephen as follows:

(3) A kills B knowing that he is killing B, and knowing that it is illegal to kill B, but under an insane delusion that the salvation of the human race will be obtained by his execution for the murder of B, and that God has commanded him [A] to produce that result by those means. A's act is a crime if the word "wrong" means illegal. It is not a crime if the word means morally wrong.

J. Stephen, A History of the Criminal LaW of England 149 (1883). 
theory of the law, are made by God, and it is in His image that they act and speak...

$$
\text { Judge Porter to the Jury }{ }^{138}
$$

Since no one but (arguably) Guiteau took seriously his "higher law" defense of Abrahamic insanity, the law could operate in its own categories. Avoiding the higher law question posed by a divine command to murder in which people believed, the system could deal with the legal implications of Guiteau's possible belief in his own inspiration. But it was exactly this certainty that there had been no divine command to Guiteau to kill James Garfield which created another problem clearly seen in connection with the Freeman case. As the Independent noted, the question of importance posed by Freeman's murder of his daughter was not essentially legal, and it was a question "asked much more in private than in public:"

If it was a horrible offense for Freeman to offer his child as a sacrifice, at what he believed fully to be God's command, why was it not just as horrible an offense for Abraham to try to do the same? In other words, if the nature of the fact supposed to be commanded proves that it could not have come from God in the case of Freeman, can the same command have come from God in the case of Abraham? ${ }^{139}$

This would, the newspaper suggested, be a "fresh" question to some, "because in the story which we have heard from our childhood the element of horror is absent. . ." But clearly the problem was that "what was faith in Abraham we call fanaticism now."140

Some ministers considered the divine origin of a command to kill very explicitly when discussing Freeman. When a person comes claiming "that he has received a divine command to sacrifice his

138. 2 Trial, supra note 1 , at 2268.

139. Id. Rosenberg refers to The Independent as "one of the country's more influential weeklies." ROSENBERG, supra note 1 , at 23.

140. Abraham, Isacc and Pocasset, The Independent, May 22, 1879, at 14, col. 1. It has been noted that for the modern reader, the story of Genesis 22 is extraordinarily difficult. "Modern readers find the picture of God's temptation of Abraham to sacrifice his own son repulsive. The horror which human sacrifice excites makes it hard for them to see how God could utter such a command even when it is not seriously intended, or how Abraham could have accepted such a command as a true divine revelation. ..." McKenzie, The Sacrifice of Isaac (Gen. 22), 9 SCRIPTURE 79 (1957).

On "the legends and lore of the command to Abraham to offer Isaac as a sacrifice," see $\mathbf{S}$. Spiegel, The Last Trial (J. Goldin trans. 1969).

The treatment of Abraham by Kierkegaard (FEAR AND TREMBLING), while published in 1843, was not available in English until the twentieth century. Krauschoor, Kierkegaard in English, 39 J. OF PHILOs. 561 (1942). German translations were available somewhat earlier than English translations. 
child," and then he "cites the Old Testament command to Abraham to slay Isaac, and the New Testament belief in the resurrection of a slain body to support him ..." how should one respond? ${ }^{141}$ One response to Freeman's acts was an attack on uncritical biblical literalism and dogmatic theology. Freeman "has been taught from his infancy to read this [the story of Abraham] as an exemplary and typical act, some argued, but he really "needed somebody bold enough to tell him that the record was only the story of a savage superstitious Arab. It's all true enough, no doubt, but it's only a true and beautiful story about an old patriarchal tramp who lived in the early and primitive ages of the world, but who if he lived today would be sent to the penitentiary or insane asylum. His act was very fitting and proper in an age of superstition and ignorance, but today it would be simply infamous." But this reading, one minister noted, "will be called sacrilegious by the Methodists of this city, simply because they have invested the Bible with a superstitious reverence, and have been accustomed to override the noblest and purest instincts of our nature by commending such characters for examples." "The truth is," the clergyman concluded, that Abraham "is a picture of human nature and a character worth studying, but he is no more worthy of our imitation today than a Fall River tramp would be."142

In a discussion called "The Pocasset Tragedy: The Legitimate Fruit of Christianity," the free thinker and spiritualist William Denton emphatically pointed out: "When this man is tried," he said, "Christianity and Judaism will be tried," for did not Freeman have "as much right to obey what he believed, and still believes, was the command of God, as Abraham had?" More than that, "If Abraham is to be praised, and his faith commended, how much more should Christians commend Freeman, who trusted when Abraham failed!" As Denton recalled, "there were Christians saying that Freeman should be hanged, that he was unfit to live." But, "when you hang Freeman, you hang Abraham and Jehovah, who were equally guilty, and condemn your religion, which was the parent of his crime." The point for Denton was that the causes of the crime "not only belong to orthodox Christianity, rather they are its very heart."143

141. Potter, The Commands of the Lord in A History of THe Pocasset Tragedy WITH the Three Sermons Preached in New Bedford by Rev. William J. Potter, Rev. C.S. Nutter \& Rev. W.C. Stiles 13 [hereinafter History of the Pocasset Tragedy].

142. Stiles, The Bible and Human Reason in History Of THE Pocasset Tragedy, at 31 .

143. W. Denton, The Pocasset Tragedy: The Legitimate Fruit of Christianity 28 (1882). This pamphlet (not listed in McDades bibliography, The Annals of Murder) can be found in the Denton collection at the University of Pennsylvania and at the Newberry Library. 
And finally, it is interesting to see the reaction of the American Socialist, ${ }^{144}$ the newspaper of the Oneida Community, to the Pocasset murder. Certainly, the community frequently attacked for its own religious behavior did not attempt to defend Freeman. Their newspaper referred to Freeman's "fanaticism," and "wickedness." But the community's essential position was that clergy and religious journals "only made-lame apologies" for Abraham when they argued that "owing to his barbaric conditions and surroundings he was led astray, or that he misunderstood the command of God, or that the record itself is an example of oriental extravagance and, therefore, is untrustworthy as history." The true position to take, the American Socialist $^{145}$ urged, "was that Abraham had been for a long lifetime in open communication with the angelic world ..." and when he was put to the "severest possible test of faith, his obedience was perfect." Abraham's was a "noble, godlike act, and fully justified by the results." By Abraham's act it was "forever demonstrated that in the religion of the God of Abraham, obedience is better than sacrifice," 146 and that in that religion, human sacrifices never were to have a place.

Not surprisingly, the Guiteau case led to similar arguments about the biblical literalism in the Abraham and Isaac story. ${ }^{147}$ While some observers envisioned Guiteau as drawing his inspiration from

I appreciate the courtesy of both of these institutions. See also W.H. LITTLEJOHN, THE PoCASSET TRAGEDY: FREEMAN NOT a SEVENTH-DAY ADVENTIST (1879). I have been unable to locate a copy of Poor Little Edith Freemen. The Pocasset Fanatics - Chas. Freeman, the "Second Adventist" imagining himself another Abraham slays his little daughter, offering up his darling child as a human sacrifice. (Phila. 1879) (listed in McDade's bibliography as item 322). It is neither, I am advised, in the collection of the American Antiquarian Society (McDade's reference) nor the collection of the Pennsylvania State Library (N.U.C. reference).

144. The Pocasset Tragedy, American Socialist, May 29, 1879. The Perfectionist spokesman then argued the group's central theological proposition, that the Second Coming had already occurred. Freeman and wife and neighbors "carried their fanaticism to extreme wickedness"; and might be condemned and living, or imprisoned for life." There is, significantly, no emphasis on the insanity issue here.

Perfectionism, too, could be considered in the context of barbaric Christianity. Thus, Reverend Powell wrote, "I wish it were possible ..." he said, "to say that 'all the blame lay on such fanatical institutions' as Oneida. But we are quite entitled to say to Noyes \& Co., 'your inspiration is a lie, but ours is the truth?' You go back to patriarchal times, to Abraham and concubinage, for your ideal; we go back only to Apostolic times . . . " Powell, GuIteAU FROM A THEOLOGical STANDPOINT 7 (1881).

The Millerite excitement earlier in the century also came up at the Guiteau trial as illustrating fanaticism but not insanity. See 2 Trial, supra note 1, at 1368.

145. Id.

146. Id.

147. See Reddy, Abraham's Inspiration in the Offering of Isaac, His Son, Christian ADvOCATE, March 30, 1882. "The blasphemous use of the case of Abraham by Guiteau and its frequent citation by fanatics, justifies a careful examination of the Scripture narrative at this time." 
atheism, and "from the fashionable Godless theories that flood the public press and public mind," 148 and The New York Times (in an odd example of denial) suggested parallels in the writings of the ancient Greeks, ${ }^{149}$ a number of observers, particularly those associated with liberal Christianity and more secular orientations, saw Guiteau as someone who stood solidly within one aspect of the Christian tradition. These writers used the case of Guiteau, as some had used the case of Freeman, to press home a call for critical reason. Moncure Conway, noted that a day might come when a plea for Guiteau might argue that he was a victim of the worst teachings of morbid [Christian] dogma which were impressed on his mind in early life and were exaggerated by his morbid temperament. Guiteau was taught that the supreme object of existence was to save his own soul-that first lesson in selfishness taught to millions of children (which only the restraining grace of human nature prevents from making them soulless!) "and was trained to believe that with God, human goodness availed nothing." He was taught "that death was a small affair, and to a Christian great gain, passage from an accursed world to a blissful paradise." And, finally, the "only fatally wicked thing was to him unbelief." These dogmas, Conway said, "were given him as the guides of his life," but, they were "a perilous kind of teaching."1so

The relationship of Guitean to traditional christianity was at least once elaborately presented in a sermon. Reverend E.P. Powell of Utica New York offered this analysis: "Guitean insists that he was the subject of special divine inspirations." Theologically, Reverend Powell said, inspiration is not absurd, but an allowed possibility. Indeed, [belief in inspiration is a necessity]. . . Eternal death or misery hangs on the blasphemy of denying inspiration." 151

Reverend Powell then debated the point with an imaginary antagonist: "You answer that the inspiration of Guiteau is impossible" since this is a "case of murder and God would not inspire a man to do

148. See T. EASTON, ISRAEL's BEAUTY SLAIN 14 (1881), for a sermon associating Guiteau with the Nihilistic contempt of all "authority, human, or divine, which feeds upon and springs out of the rotten compost of Atheism."

149. The New York Times said: "It is a very strange recreation of the meddling pagan Gods of the Greek mythology that Guiteau has attempted. There is a very curious and complete parallelism between the view of the crime and the most striking feature of the theology of the Greeks. Their theory of the nature of the Gods and of their relations with men was precisely that which Guiteau pretends to hold of the Divine nature and its manifestations in our day." New York Times, January 1, 1882, at 6, col. 6 .

150. M. Conway, The Life and Death of Garfield: A Discussion Before the South Place Religious Society 17-18 (1881).

151. E. Powell, Guiteau from a Theological Standpoint $2 \cdot 3$ (1881). 
evil." But, said Rev. Powell, consider Abraham and Isaac. It is true first that Isaac was saved, and second that it "looks very much as if it was a story coming down from days of human sacrifice, when parents were accustomed to offer up their firstlings to their gods." But still, said Powell, "It is clear that Abraham meant to obey God and intended to kill his boy. It did not occur to him that it was impossible that Jehovah should inspire murder." And if Guiteau calls it removing Garfield; perhaps Abraham called it removing Isaac. And then the next question, "You claim that Guiteau if he really believes he was inspired was insane." But, Powell said, "Is such a claim proof of insanity?" What can then be said of the writers of the Bible? "What do you say is the mental condition of a man who will affirm that SOME ONE (Sic)ELSE is inspired? Is he also a crank? He recalled the Meadow Orchard Massacre in Utah. ${ }^{152}$ "A devilish affair you say; implying it was inspired of the devil. But how can one know? How shall he determine his inspiration? You answer by searching prayer, but that of course was what Guiteau did."

Finally, Reverend Powell said, "there seems to be but one safe course; and that is to understand that the reason is the only possible guide to duty." And, he concluded, "It is pleasant to believe that this trial is compelling theorists to ask how do we know that any man was ever inspired by God-and they must ask further-are we not responsible for Guiteauism." It is, he said, "a very healthy sign that men begin to pronounce it a proof of insanity to claim inspiration."153

Robert Ingersoll blamed the clergy for charging the assassination to infidelity and insisted on seeing Guiteau as a Christian. "I am exceedingly glad that Guiteau is not an Infidel," he said, "I am glad that he believes the Bible, glad that he has delivered lectures against what he calls Infidelity, and glad that he has been working for years with the missionaries and evangelists of the United States." Guiteau, Ingersoll said, "is a man of small brain, badly balanced, [who] believes the Bible to be the word of God., He believes in the reality of heaven and hell. He believes the miraculous. He is surrounded by the supernatural ..." and, Ingersoll, insisted, "when a man throws away his reason, of course no one can tell what he will do. He is liable to become a devotee or an assassin, a saint or a murderer; he may die in a monastery or in a penitentiary."154

152. Id. at 4.

153. Id.

154. THe Works of Robert Ingersoll 102-03 (Dresen 1900). See also M. MARTY, THE INFIDEL: Free ThOUGHT AND AMERICAN RELIGION (1961). 
The invocation of Abraham by Guiteau raised, then, a troublesome problem because it came all too close to a debate between liberal and orthodox Christianity, orthodoxy maintaining that the bibical account was true, but that the age of revelation was over, while liberals suggested that the biblical account itself was open to question. Under the argument of Guiteau's insanity and the question of reason and unreason, there was, in short, a sensitive issue which related to reason and revelation. Orthodoxy's answer to Guiteau was provided by people at the trial, including Gray, Porter and Davidge. In explicitly religious terms, the editor of the Christian Advocate quoted the New Testament (James 13): "There is nothing new in this case. St. James understood it, and states every principle involved in it: Let no man say when he is tempted, I AM TEMPTED OF GOD; for God cannot be tempted with evil, neither tempteth he any man: But every man is tempted, when he is drawn away of his own lust, and enticed. Then, when lust hath conceived, it bringeth forth sin; and sin, when it is finished, bringeth forth death."15s Prosecutor Davidge quoted the same passage at the trial: "[t]hat was the inspiration," he said, and " $[t]$ hat is my commentary generally upon what you have heard here in respect of divine pressure."156

An English psychiatrist also responded to Guiteau's argument in religious terms. He suggested that the judge and jury might say: "We also believe in the inspiration of the Almighty, and we have prayed to Him that He will enable us to give a just judgment upon you, and our judgment, inspired by Him who is the source of all justice, is that you are Guilty, as indicated, and that you must suffer the penalty of your crime."157

Finally, Guiteau was hanged and as Professor Rosenberg indicated, it is "only common sense" to say that no jury would have acquitted him. The death of Garfield meant the death of Guiteau. Dr. Godding, Superintendent of Washington's Hospital for the Insane, wrote later: "I said then, If the President dies, no plea of insanity can save this man from the gallows; if the President lives, no commission of lunacy will fail to find him insane. ..."158 Similarly, Dr. George Beard, the well-known neurologist, was convinced of Guiteau's in-

155. Buckley, A Study of Guiteau, Christian Advocate, Jan. 12, 1882, at 18, col. 2.

156. 2 Trial, supra note 1 , at 1918.

157. Bucknill, The Pleas of Insanity in the Case of Charles Julius Guiteau, 39 AM. J. INSANITY 181, 198 (1882-1883) (reprinted from BraIN 1882).

158. W. Godding, Two Hard Cases: Sketches from a Physician's Portrolio 37-38 (1882). 
sanity and believed that Guiteau would not even have been tried if he had killed a common citizen or had missed the President. "There is no asylum in the world, public or private" Beard wrote, "that would not have taken Guiteau at once, at any time during the past twenty years, and kept him as long as his friends desired to have him remain, on the certificate of any physicians who might or might not have known anything about insanity,"159 And reformer Wendell Phillips explicitly and with some intensity deplored the motivations likely to be involved in any execution of Guiteau: "if, carried away by hot revenge, the people hang him, it will be a blot on the justice of the American people which probably within five years, men would do anything to erase." History would record it, Phillips said, "as one of the most lamentable instances of temporary madness, or as evidence how much of actual barbarism lingers in the bosom of an intelligent and so-called Christian community."160

But what else did the judgment mean? Is it possible to say more than that a century ago the assassin of a President had to die at the hands of the legal system? Of course, we can never really know why the jury decided as it did. It is to be assumed that the jurors believed that there had been no revelation to Guiteau in fact. For the rest, the jurors may have simply thought that Charles Guiteau was lying and that he did not believe in the idea of his own inspiration. Or they may have believed that because there was no claim of sensory experience there was no "delusion" according to the law as laid down by Judge Walter Cox. Or they may have thought that Guiteau believed that he was "inspired," but that his belief (as some had argued concerning Charles Freeman) was simply punishable fanaticism.

Perhaps this much is also true, however: any trial which is so elaborately discussed in public has social and religious aspects larger than the technical legal problems involved. ${ }^{161}$ "Many of the features

159. Beard, The Case of Guiteau: A Psychological Study, 9 Journal of Nervous DisEASES 9 (1882). (Emphasis in original) For Beard's brief appearance at the trial, see 2 Trial, supra note 1 at 1718 .

160. Phillips, The Death Penalty, 133 North American Review 550, 559 (1881).

161. Thus, Paul Carter on the highly publicized civil suit of Henry Ward Beecher (brought in 1875 by Theodore Tilton, for alienation of affections): "Conceivably Tilton $v$. Beecher was one of the great symbolic trials, like those of Bukharin or Dreyfus or Alger Hiss-the kind in which in the minds of partisans the accused must be guilty or must be innocent because of larger issues that turn upon that guilt or innocence." P. Carter, The SPIRITUal Crisis of THE GILded AGe 118 (1971). Professor Carter is careful to state that we cannot tell how many people rejected this reading of the trial's significance. Id. at 248 and n.41. See generally W. Mclaughlin, The Meaning of Henry Ward Beecher: An Essay in the Shifting VALUES OF MID-VICTORIAN AMERICA 1840-1870 (1970).

If things other than the speeches of doctors and lawyers were important in the Guiteau 
of the personal history of Guiteau will be recognized," John Gray wrote in the American Journal of Insanity: "They are by no means uncommon or incredible in our days, under the system of extreme liberty, not to say license, both of opinions and conduct allowed by the institutions of modern civilization."

In an age when almost all authority is disregarded as to religious belief and social conduct, it is not extraordinary to find even the most destructive principles as well as the most transparent impostures brought under the cloak of religion, until society is almost forced to inquire how far the 'rights of conscience' are to be respected when the good order and peace of the State begin to be imperiled. ${ }^{162}$

Gray's emphasis on authority in relation to religious belief and opinion as well as practice is obvious, and not surprisingly, he linked this breakdown to authority to the problems posed by Mormonism and loose divorce laws.

Finally, it is entirely possible that as important as contending psychiatrists' speeches, and the jury instructions given by Judge Cox, were the comments of Judge Porter ${ }^{163}$ for the prosecution, particularly his long speech to the jury. ${ }^{164}$ Judge Cox in his instructions suggested two pictures of religious belief, one sane and one insane, for the jury to examine. But neither picture is comparable to the one drawn by Judge Porter, who raised quite a different image in refutation of both Guiteau's arguments and the arguments of the defense psychiatrists. Porter's address was described as "devoted largely to portraying and denouncing with scathing invective the character of the accused ... It described the prisoner as a monster of iniquity. ..."16s But these denunciations had a very particular quality. Repeatedly, Porter associated Guiteau with the devil, ${ }^{166}$ and suggested that argu-

trial, what other things were they? Mitchell, The Man Who Murdered Garfield, 67 MASS. Hist. SoCieTY ProceEdings 452 (1941), stresses the testimony of Guiteau's former wife, Mrs. Theodore Dunmire, to the effect that she had never seen anything indicating that Guiteau was a man of unsound mind. Id. at 475 (quoting 1 Trial, supra note 1, at 1165-66). Mitchell writes that this testimony "probably did more to send [Guiteau] to the gallows than all the lawyers and doctors put together." Id. at 475.

162. Gray, The Guiteau Trial, 38 AM. J. INSANITY 303, 309 (1882).

163. Porter, who had briefly been a judge in New York, was one of those representing Beecher (and Christianity?) in the Beecher-Tilton trial. See also Biographical Sketch of John K. Porter (1819.1892), N.Y. State Bar Ass'N Reports 125-30 (1893).

164. For Rosenberg's summary, see supra note 1, at 200-01.

165. Guiteau's Trial, APPLETON'S ANNUAL CYCLOPEDIA AND REGISTER OF IMPORTANT EVENTS 381,394 (1881).

166. The present emphasis on Porter, and this highly literal reading of his speech, does not deny the importance of tendencies represented to Spitzka or others of a secularist mentality. 
ments in support of Guiteau would excuse the ultimate evil. If Lucifer "happened to be on trial," Judge Porter said, "I wonder what Dr. Spitzka would say of him."167

Porter was consistently aware of his religious context, and an identification with the idea of a Christian Nation is evident in his remarks at the trial and in his long and emphatic speech. Porter argued that his colleague "had shown greater forbearance in dealing with Guiteau than that exercised in any state trial reported in Christendom." He objected to a question "as irrelevant and blasphemous."168 Even as a young man, Porter said, Guiteau had been "possessed of the spirit of diabolism." 169

Judge Porter also responded directly to the issue of Abrahamic insanity. The insanity described as temporary mania or as moral insanity or congenital monstrosity is, he said, "described better by that most eminent scientist, Dr. Barker, as simple wickedness." It was hereditary insanity, Porter said, but it is "inherited, not from the natural parent, but from another source." 170 Judge Porter said, "I reminded you yesterday, of the rebuke of the Savior to the scribes and Pharisees: 'Those who are of the seed of Abraham prove it by doing the works of Abraham: but we are the children of your father the devil, who was a murderer from the beginning." " This, said Porter, is the order of hereditary insanity, which he has derived from the source, laid bare by the Saviour of mankind, and of which you see so striking an illustration in the prisoner's dock." 171 Porter character-

The point is that Porter (and Gray) were in part engaged in a discussion of reality with others whose world view no longer, as David Hall says, located truth in the Christian revelation. Hall, The Victorian Connection, in Victorian AMERICA 81 (D. Howe ed. 1976).

167. See 2 Trial supra note 1 , at 2301 . Porter argued that "the claim in the present case is, that this man was so enormously wicked as to be, in the language of Dr. Spitzka, an absolute 'moral monstrosity'. But, said Porter, "He represents the distinctive class of whom the Savior spoke, not as lunatics, but as possessed with devils." Id. at 2266 (emphasis added).

168. Id. at 1493.

169. Id. at 2230 .

170. Id. at $2272-73$.

171. Id. at 2305. A tone similar to that of the closing speech was evident also in Porter's questioning of Guiteau. See 1 Trial, supra note 1 at 605. Professor Rosenberg's description of Porter includes these aspects. Porter, he writes, was: "a most persistent questioner, Guiteau a picture of frustration, unable to explain the simple truth of his inspiration to the older man... Porter delighted as well in ridiculing Guiteau's theological pretensions-quoting Noyes' Berean to prove that the defendant had simply plagiarized his religious ideas from the Oneida Community's founder." Rosenberg, supra note 1 , at 141.

Porter's view of the case may be contrasted with the neutral statement offered by Judge Cox:

The theory of the Government is that the defendant committed the homicide in the full possession of his faculties and from perfectly sane motives; that he did the act from revenge, or perhaps from a morbid desire for notoriety; that he calculated delib- 
ized Guiteau as diabolical. The word could carry, in addition to its looser meaning, a specific literal reference. All this, it may be suggested, is more clearly characterized as religious disputation than law.

erately upon being protected by those who were politically benefitted by the death of the President and upon some ulterior benefit to himself; that he made no pretense to inspiration at the time of the assassination, nor until he discovered that his expectations of help from the so-called stalwart wing of the Republican party were delusive, and that these men were denouncing his deed, and that then for the first time, when he saw the necessity of making out some defense, he broached this theory of inspiration and irresistible pressure, forcing him to the commission of the act.

2 Trial, supra note 1 , at 2341-42.

The religious/secular theme emerged also in the examination of witnesses by the prosecution lawyers. Dr. Godding writes:

At the second question he drew out the fact that the witness [Kiernan] did not believe in a future state of rewards and punishments; and though this was not, strictly speaking, a scientific refutation of the prisoner's insanity, it was in effect to make a philistine of this witness to the jury, who had stated under oath that they believed in the doctrines of the Christian religion.

W. Godding, Two Hard Cases: Sketches from a Physician's Portfolio 187 (1881). Rosenberg comments that "for many of the jurors, Kiernan's testimony could, from that moment, be disregarded." RosenberG, supra note 1, at 146.

See also the examination of Spitzka:

District Attorney Corkhill. Do you believe in God?

The Witness [Spitzka]. If the court does not declare your question irrelevantdoctor

The Court [Cox]. (Interposing) You are not obliged to answer that question,

[Spitzka]: I do on principle, decline to answer question . . . . or not?

Corkhill: Then I understand you decline to answer whether you believe in God

Spitzka: I decline to answer it on principle, as from my point of view, an impertinent question in a country that guarantees civil and religious liberty.

Mr. Davidge: Irreligious liberty. 1 Trial, supra note 1, at 1007. The defense also cited the Bible, attempting to persuade the jury to feel compassion for a lunatic.

2 Trial, supra note 1 , at 1948-49.

On devilish delusions as against insane delusions, see id. at 2310; 1 Trial, supra note 1, at 690 . Also "this malignant, diabolical, crafty, calculating cold-blooded murderer" 2 Trial, supra note 1, at 2305; see also "whether the devil that possess this man, is or is not to be checked by the mandate of law. . ." Id. at 2667.

Was there, then, a different defense available? See Wharton: then as to the alleged supernatural powers of Satan. Now the existence of Satan as a tempter is not denied; all that we deny is his absolute power as a coercer. The law of the land united with Scripture in affirming the existence of such a tempter. 'Moved and seduced by the instigation of the devil' is the allegation which the prosecution makes in every indictment for a heinous crime. 'I was coerced to do so by supernatural agency' is a defense, which, unless there be proof of insanity aliunde, is never tolerated. This is one of the points in which the common law had adopted the divine word as part of itself.

Wharton, a Treatise on Mental Unsoundness Embracing a General View of PSyChOLOGiCAL LAW $\S 645$, at 628 (1873).

Porter attempted to persuade the jury to judge Guiteau on moral and not only legal standards. Thus, "Gentlemen, it is well for us all that the law does not call on jurors to leave the only immortal part of their nature, their moral nature, at the courthouse door when they enter it to administer justice." 2 Trial, supra note 1, at 2662. 
Finally, Judge Porter was invoking a standard of religious orthodoxy against a blasphemer, a fanatic, and a murderer.

\section{CONCLUSION}

The people of this nation, neurologist George Beard observed in 1881, have "been pressed constantly with these three questions: How shall we keep from starving? Who shall be the next president? And where shall we go when we die?"172 The work of historians, including legal historians, has usually focused on the problems raised by the first two questions. Perhaps because of what Martin Marty calls the "Modern Schism," 173 the scholarship relating broadly to the third question has become part of church history, one of the tunnels ${ }^{174}$ through which historians view the past. Yet the events in the Guiteau trial had a relation to that third question. In a case involving the insanity defense, "the decision between guilt and insanity has a symbolism transcending an individual's fate." 175 Sometimes that symbolism touches the most profound issues not only of morals and ethics but of ultimate realities. The result of the Guiteau trial is what the jury decided on the question of Guiteau's insanity. That is clear enough. More difficult is the problem of determining what the jurors really thought about Guiteau's defense. Perhaps they thought that he was lying. Perhaps that he was blaspheming. Perhaps that he was simply sane, according to the contemporary law.

It has been argued here that Guiteau's assertion that he was like Abraham meant more to his time than it does to ours, and that the legal responses to that assertion, in a culture which debated the literal truth of the Bible, contained reflections of that large debate. Reading the trial of Guiteau as an intersection of legal and religious issues, one may suggest the following: In finding Charles Guiteau sane and guilty of the assassination of James Garfield, a jury could have been doing several things in addition to declaring an individual assassin guilty of murder. If the jury considered the case in the light suggested here, it would have been ruling against the agnostic materialism of defense psychiatrists, Spitzka and Kiernan, and for the religious orthodoxy represented by prosecution lawyer, John Porter, and prose-

172. G. Beard, American Nervousness: Its Causes and Consequences 128 (1881).

173. M. Marty, The Modern Schism: Three Paths to the Secular 9 (1969).

174. J. HEXTER, REAPpraisals IN HISTORY: NeW VIEWS ON History AND SOCIETY IN EARLY MODERN EUROPE 258 (2d ed. 1979).

175. R. Smith, Trial ay Medicine 3 (1982). 
cution psychiatrist, John Gray. It would also have been implicitly denouncing a form of religious fanaticism widely understood as analogous to that of the Mormons and the Oneida Perfectionists, a fanaticism associated in the minds of contemporary observers with a number of crimes and immoralities of which the assassination of President Garfield was the latest and most terrible example. 
$$
\text { . }
$$ 